\title{
Biostratigraphy and paleoecology of the Oligo-Miocene Asmari Formation in the Izeh zone (Zagros Basin, SW Iran)
}

\author{
Mohammad Reza Taheri, Hossein Vaziri-Mogaddam, Azizollah Taheri, Ali Ghabeishavi
}

Mohammad Reza Taheri Hossein Vaziri-Mogaddam

avaziri7304@gmail.com

Department of Geology, Faculty of Science, University of Isfahan, Isfahan, 81746-73441, Iran

\section{Azizollah Taheri}

Geology Department, Faculty of Earth Science, Shahrood University of Technology, Shahrood, Iran.

\section{Ali Ghabeishavi}

National Iranian South Oil Company

(NISOC), Ahwaz, 61735-1333, Iran.

BOL. SOC. GEOL. MEX. 2017

VOL. 69 NO. 1

P. $59-85$

\begin{abstract}
In this study, biostratigraphy and paleoecology of the Asmari Formation have been investigated. The study area is located in the Izeh zone, Zagros Basin. Four outcrop sections (Halayjan, Kuh Shur, Kuh-e Bad and Gharibi $\mathrm{Ha}$ ) have been sampled. Based on distribution of the larger benthic and planktonic foraminifera, five assemblage zones have been recognized. Assemblages 1 and 2 indicate Chattian; assemblage 3 is restricted to Aquitanian and assemblages 4 and 5 suggest Burdigalian. During the Chattian, the carbonate deposits of the Asmari Formation are mostly composed of coralline red algae and large and flat benthic foraminifera. The common components of the Aquitanian are abundant imperforate foraminifera and Favreina asmaricus. The Burdigalian is characterized by coral, coralline algae, and perforate and imperforate foraminifera. During the Burdigalian toward the SE of study area (Gharibi Ha section), the shallow water deposits are abruptly overlain by pelagic limestone. It is interpreted as the result of a regional tilting that started in the upper part of the Burdigalian.

The biotic associations suggest that carbonate sedimentation occurred in tropical to subtropical waters under oligotrophic to mesotrophic conditions. The carbonate grain associations in the Asmari Formation suggest heterozoan association. According to paleoecological parameters (such as: nutrient, depth, light and salinity) in the study area, the Asmari Formation belongs to nannofor - foralgal to foramol association which were deposited in slightly hyper to normal saline environment. In the euphotic zone, abundant imperforate foraminifera are present. Basinward, lens shaped rotalids developed in mesophotic conditions, and large lepidocyclinid-nummulitids characterize the sediments of the deeper oligophotic zone.
\end{abstract}

Keywords: Asmari Formation, Oligocene-Miocene, biostratigraphy, paleoecology, larger benthic foraminifera, Zagros Basin.

\section{RESUMEN}

En este estudio, investigamos la bioestratigrafia y paleoecología de la Formación Asmari. El área de estudio se localiza en la zona de Izeh, Cuenca de Zagros. Cuatro secciones en afloramientos fueron muestreadas (Halayjan, Kuh Shur, Kuh-e Bady Gharibi Ha). Con base en la distribución de grandes foraminíferos bentónicos y planctónicos, cinco zonas de asociación fueron reconocidas. Las asociaciones 1 y 2 indican una edad correspondiente al Chattiano; la asociación 3 está restringida al Aquitaniano, y las asociaciones 4 y 5 sugieren una edad correspondiente al Burdigaliano. Durante el Chattiano, los depósitos de carbonato de la Formación Asmari, fueron compuestos principalmente por algas coralinas y rojas, así como por foraminíferos bentónicos grandes y aplanados. Los componentes comunes en el Aquitaniano son abundantes foraminiferos impreforados y Favreina asmaricus. El Burdigaliano se caracteriza por corales, algas coralinas y foraminiferos perforados e imperforados. Durante el Burdigaliano, hacia el SE del área de estudio (sección Gharibi Ha), los depósitos someros son sobreyacidos abruptamente por caliza pelágica. Lo anterior se interpreta como el resultado de una inclinación regional, que inició en la parte superior del Burdigaliano.

Las asociaciones bióticas sugieren que la sedimentación de carbonatos ocurrió en aguas tropicales a subtropicales, en condiciones oligotróficas a mesotróficas. Las asociaciones de granos de carbonato en la Formación Asmari, sugieren una asociación heterozóica. Con base en parámetros paleoecológicos en el área de estudio (tales como: nutrientes, profundidad, iluminación y salinidad), la Formación Asmari corresponde a una asociación de nanoplancton/foraminiferos - foraminiferos/algas, a foraminiferos/moluscos, depositadas en un ambiente con condiciones ligeramente hipersalinas a salinas normales. En la zona eufótica se presentan abundantes foraminiferos imperforados. Hacia la parte profunda de la Cuenca se desarrollaron rotálidos lenticulares, bajo condiciones mesofóticas, y grandes lepidociclinas-numulites, caracterizan a los sedimentos de la profunda zona oligofótica

Palabras clave: Formación Asmari, Oligoceno - Mioceno, bioestratigrafía, paleoecología, grandes foraminíferos bentónicos, Cuenca de Zagros. 


\section{Introduction}

The Zagros mountain belt of Iran, a part of the Alpine-Himalayan system, extends from the NW Iranian border to SW Iran, up to the Strait of Hormuz (Figure 1A) (Heydari et al., 2003). It can be divided into a number of zones (Lurestan, Izeh, Dezful Embayment, Fars, High Zagros), which differ according to their structural style and sedimentary history (Figure 1B). The Asmari Formation is a stratigraphic unit, mostly composed of limestone with subordinate sandstone and shale of approximately Oligocene-Early Miocene age. This formation was developed regionally across the Zagros Mountain range, prograding from the north and the south into the Eocene-Early Miocene Pabdeh Formation (James and Wynd, 1965; Seyrafian et al., 1996). The Asmari Formation is the main petroleum reservoir in southwest Iran (Beydoun et al., 1992).

Lithologically, the Asmari Formation, at the type section in Tang-e Gel-e Tursh (Valley of Sour Earth) on the southwestern flank of the Kuh-e Asmari anticline, consists of $314 \mathrm{~m}$ of mainly limestone, dolomitic limestone and argillaceous limestone (Motiei, 1993). The shallow marine limestones of the Asmari Formation were conformably deposited over the Pabdeh Formation in the southwestern part of the Zagros Basin (Figure 2) and also unconformably covered the Jahrum and Shahbazan Formations to the northeastern part in the Fars and Lurestan regions (Figure 2). The Oligocene-Miocene in SW Iran is mostly characterized by exclusively shallow water carbonates.

In all studied sections the contact of the Asmari Formation with the underlying Pabdeh Formation is transitional and conformable. The upper contact with Gachsaran Formation is conformable in all studied sections. The Asmari Formation in the study area is mainly composed of thick to medium bedded and massive limestone and subordinate marl and dolomitic limestone intercalations. The overall thickness of the formation vary from northwest to southeast including $330 \mathrm{~m}, 325 \mathrm{~m}$,
$415 \mathrm{~m}$ and $416 \mathrm{~m}$ in the Halayjan, Kuh Shur, Kuh-e Bad and Gharibi Ha, respectively.

The biostratigraphy of the Asmari Formation was outlined by Wynd (1965) and reviewed by Adams and Bourgeois (1967). Adams and Bourgeois (1967) introduced four assemblage zones for the Asmari Formation (Table 1). They did not differentiate Rupelian from Chattian. These two reports were used by many authors (e.g., Seyrafian, 2000; Vaziri-Moghaddam et al., 2006; Amirshahkarami et al., 2007a, b).

Recently, Ehrenberg et al. (2007), Laursen et al. (2009) and Van Buchem et al. (2010) conducted strontium isotope dating to improve the biostratigraphic ages for the Asmari Formation across most parts of the Zagros basin (Izeh zone and Dezful Embayment) (Table 2). This biozonation is used by many recent authors (e.g., Allahkarampour Dill et al., 2010; Van Buchem et al., 2010; Sooltanian et al., 2011; Rahmani et al., 2012). The biozonation scheme of Laursen et al. (2009) and Van Buchem et al. (2010) have some basic differences compared to the old scheme (Adams and Bourgeois, 1967). In the old scheme, the noticeable thickness of the Asmari limestone, containing Archaias, has been considered Aquitanian. Today this interval proved to be Oligocene. Also in the biozonation of Laursen et al. (2009) and Van Buchem et al. (2010), the Oligocene sediments are divided to Rupelian and Chattian.

The area of the new biostratigraphic studies which used the biozonation of Laursen et al. (2009) and Van Buchem et al. (2010) is very small in comparison to the total area of the Asmari basin (more than $150 \mathrm{~km} \times 700 \mathrm{~km}$ ). There are a lot of areas with unpublished sections for which the new biozonation should be considered. The studied area of this research is one of those areas with well preserved and untouched outcrop sections. The data obtained from biostratigraphic studies in this area will be used for the future regional study. The abundance of large benthic foraminifera in the limestones of the Asmari Formation offers an excellent opportunity to study paleoenvironmental controls on larger benthic foraminiferal assemblages in 


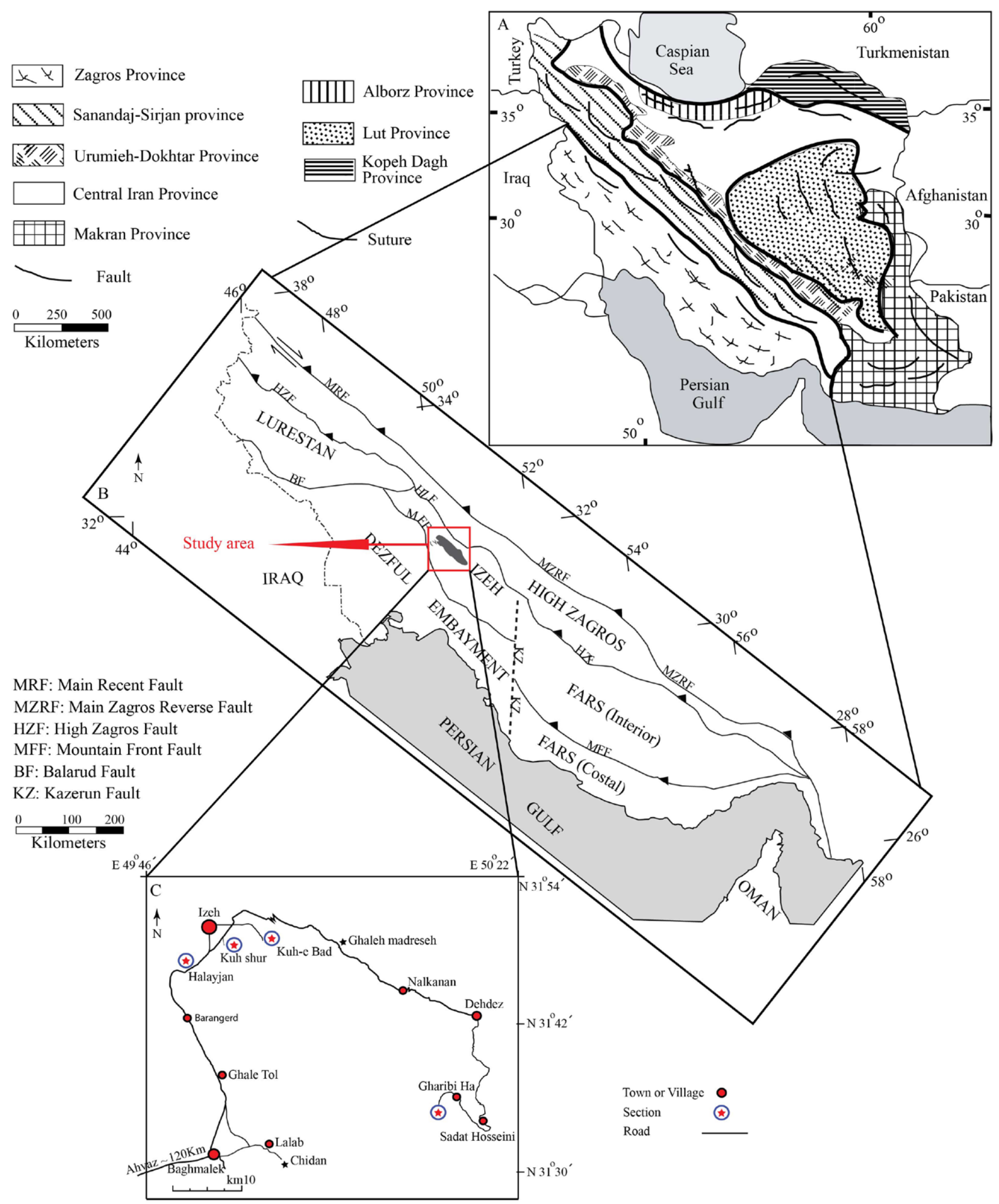

Figure 1 Location of the study area. A) General map of Iran showing eight geologic provinces (adapted from Heydari et al., 2003). B) Subdivision of the Zagros province. C) Map of the study area in the Izeh zone, southwest Iran. Halayjan (Section 1), Kuh Shur (Section 2), Kuh-e Bad (Section 3) and Gharibi Ha (Section 4). The study area is located at the Izeh Zone adapted from Farzipour-Saein et al. (2009). 


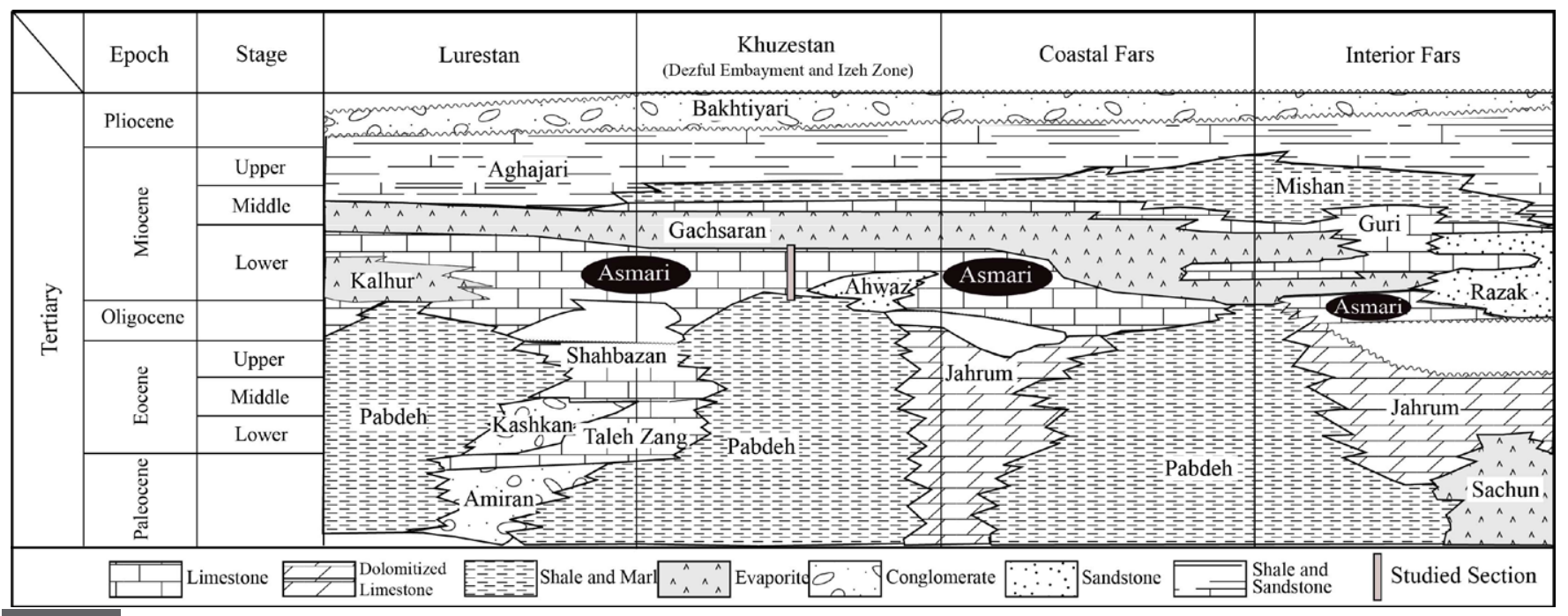

Figure 2 Cenozoic stratigraphic correlation of the Iranian Sector of the Zagros Basin adapted from James and Wynd (1965).

Table 1. Biozonation of the Asmari Formation based on Wynd (1965), Adams and Bourgeois (1967) and Cahuzac and Poignant (1997).

\begin{tabular}{|c|c|c|c|c|c|c|c|}
\hline & \multirow{2}{*}{ Age } & \multicolumn{2}{|r|}{ Wynd (1965) } & \multicolumn{2}{|r|}{ Adams and Bourgeouis (1967) } & \multicolumn{2}{|r|}{ Cahuzac and Poignant (1997) } \\
\hline & & No & Assemblage Zone & No & Assemblage Zone & No & Biozone \\
\hline \multirow{3}{*}{$\begin{array}{l}\stackrel{\Xi}{\Xi} \\
\stackrel{\Xi}{\Xi} \\
\dot{\Sigma}\end{array}$} & Burdigalian & 61 & Borelis melo curdica & 1 & Borelis melo group---Meandropsina iranica & SBZ 25 & Borelis melo curdica-Miogypsina \\
\hline & \multirow{2}{*}{ Aquitanian } & \multirow{2}{*}{59} & \multirow{2}{*}{ Austrotrillina howchini-Peneroplis evolutus } & $2 \mathrm{a}$ & Elphidium sp. 14-Miogypsina & \multirow{2}{*}{ SBZ 24} & Austrotrillina howchini-Miogypsina- \\
\hline & & & & $2 b$ & Archaias asmaricus-Archaias hensoni & & M. dehaartii \\
\hline \multirow{4}{*}{$\begin{array}{l}\mathscr{J} \\
\stackrel{0}{0} \\
.00 \\
.00 \\
0\end{array}$} & \multirow{2}{*}{ Chattian } & 58 & Archaias operculiniformis & \multirow{4}{*}{3} & \multirow{4}{*}{ Eulepidina-Nephrolepidina-Nummulites } & SBZ 23 & Miogypsinoides -Eulepidina \\
\hline & & 57 & Nummulites intermedius-Nummulites vascus & & & SBZ 22B & Nummulites vascus-N.fichteli-Eulepidina \\
\hline & \multirow{2}{*}{ Rupelian } & 56 & Lepidocyclina-Operculina-Ditrupa & & & SBZ 22A & Eulepidina formosoides \\
\hline & & 55 & Globigerina spp. & & & SBZ 21 & Nummulites vascus-Nummulites fichteli \\
\hline
\end{tabular}

detail. Sedimentary successions, representing the Oligocene-Miocene interval, allow us to evaluate the influence of change in ecological parameters through time.

The objectives of this study are (1) to reconstruct a coherent biostratigraphic framework for the carbonate deposits of the Asmari Formation in the studied area based on available biozonation schemes (Cahuzac and Poignant, 1997; Laursen et al., 2009; Van Buchem et al., 2010) (Tables 1 and 2), and (2) to present the paleoenvironmental factors which affect the distribution of biogenic components of the Asmari Formation.

\section{Material and method}

To achieve the aim of this study, four unpublished sections (Halayjan, Kuh Shur, Kuh-e Bad and Gharibi Ha) (Figures 1C and 3-5) were measured, described and sampled for paleontological and petrographical studies. The measurement was carried out using Jacob's staff. The description logs, containing lithology, texture and components (with hand lens), bedding and thickness, was prepared in the field. Around 1000 thin sections were prepared and studied to investigate texture (Dunham, 1962; Embry and Klovan, 1971) components and species identification. In this paper, LBF are used to date the carbonates using biostratigraphical zo- 
Table 2. Biozonation of the Asmari Formation, after Laursen et al. (2009).

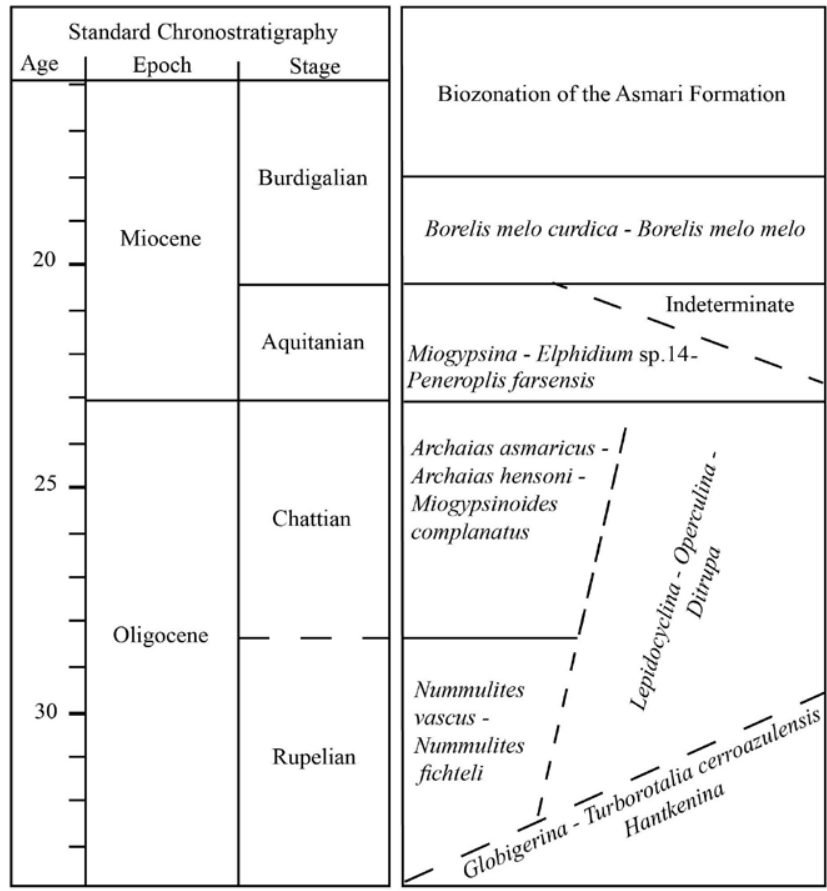

nation (Wynd, 1965; Adams and Bourgeois, 1967; Laursen et al., 2009; Van Buchem et al., 2010) and comparisons with the global Oligocene/Miocene zonation of Cahuzac and Poignant (1997) (Tables $1,2$ and 3$)$.

To have the possibility of future reinterpretation and data control, a data set containing $\sim 10000$ digital photos were prepared by using the Nikon microscope suite in the National Iranian South Oil Company lab. Nearly all of components are documented in these photos. These photos were classified and used for biostratigraphy and paleoecological interpretation. Based on this method, for every component mentioned in the biostratigraphic log, one or more photo is available.

\section{Biostratigraphy}

The Oligocene to Miocene benthic and planktonic foraminiferal assemblages, including a total of 17 genera and 23 species, were analyzed to establish the biostratigraphic framework of the Asmari For- mation in the studied sections (Figures 6, 7, 8 and 9). From base to top, five Assemblage Zones were recognized (Figures 6, 7, 8, 9 and 10).

\subsection{ASSEMBLAGE 1}

This assemblage is present in all sections and consists of Eulepidina dilatata, Eulepidina elephantina, Eulepidina sp., Nephrolepidina tournoueri, Nephrolepidina sp., Lepidocyclina sp., Heterostegina costata, Heterostegina sp., Spiroclypeus blankenhorni, Spiroclypeus sp., Operculina complanata, Operculina sp., Neorotalia viennoti, Amphistegina sp., Ditrupa sp. and globigerinids (Figure 11). This assemblage is correlated with the Lepidocyclina-Operculina-Ditrupa Assemblage Zone of Laursen et al. (2009) and Van Buchem et al. (2010), and to the SBZ 22 of Cahuzac and Poignant (1997).

Based on Laursen et al. (2009) this assemblage is attributed to the Rupelian-Chattian. However, based on Ehrenberg et al. (2007) who believes that the presence of Spiroclypeus blanckenhorni indicates a Chattian age, the age of this zone must be limited to the Chattian.

\subsection{ASSEMBLAGE 2}

This assemblage is recorded in Kuh-e Bad and Gharibi Ha sections. The most diagnostic species include: Archaias kirkukensis, Archaias hensoni, Archaias asmaricus, Archaias sp., Miogypsinoides sp., Elphidium sp.1, Peneroplis sp., Austrotrillina sp., Dendritina rangi, Meandropsina iranica, Meandropsina anahensis, Meandropsina sp., Amphistegina sp., Globigerina spp. (Figures 12 and 13). These microfauna correspond to the Archaias asmricus-Archaias hensoni-Miogypsinoides complanatus Assemblage Zone of Laursen et al. (2009) and Van Buchem et al. (2010), and to the SBZ 23 of Cahuzac and Poignant (1997), and indicate Chattian.

\subsection{ASSEMBLAGE 3}

This assemblage occurred in all sections and is defined by the concurrence of Austrotrillina howchini, Austrotrillina asmariensis, Amphistegina sp., Aus- 

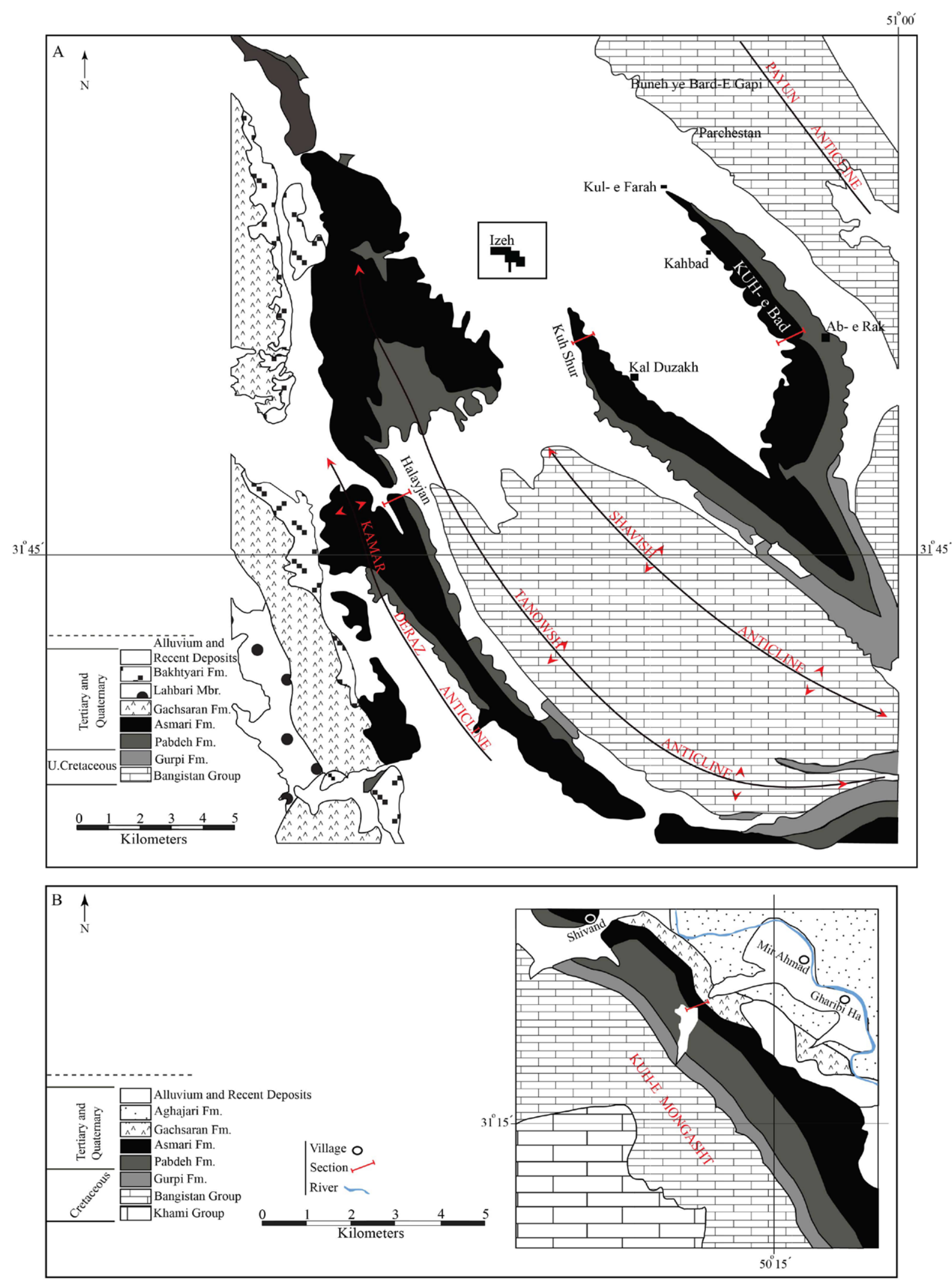

Figure 3 Location and geological map of the study area, southwest Iran. A. Halayjan, Kuh Shur and Kuh-e Bad sections. B. Gharibi Ha section, southwest Iran. 


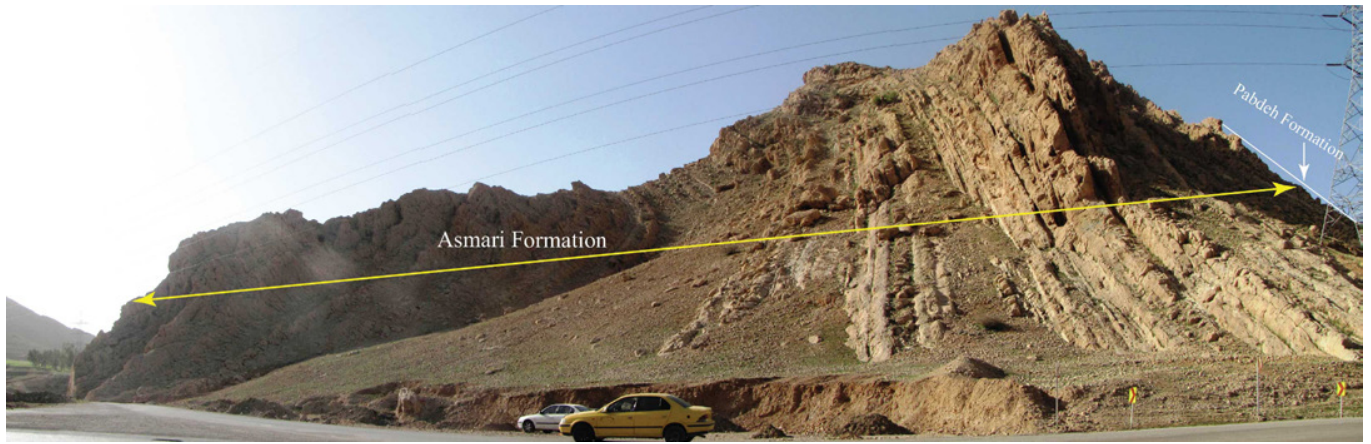

Figure 4 General view of studied section (Halayjan), view toward northwest.
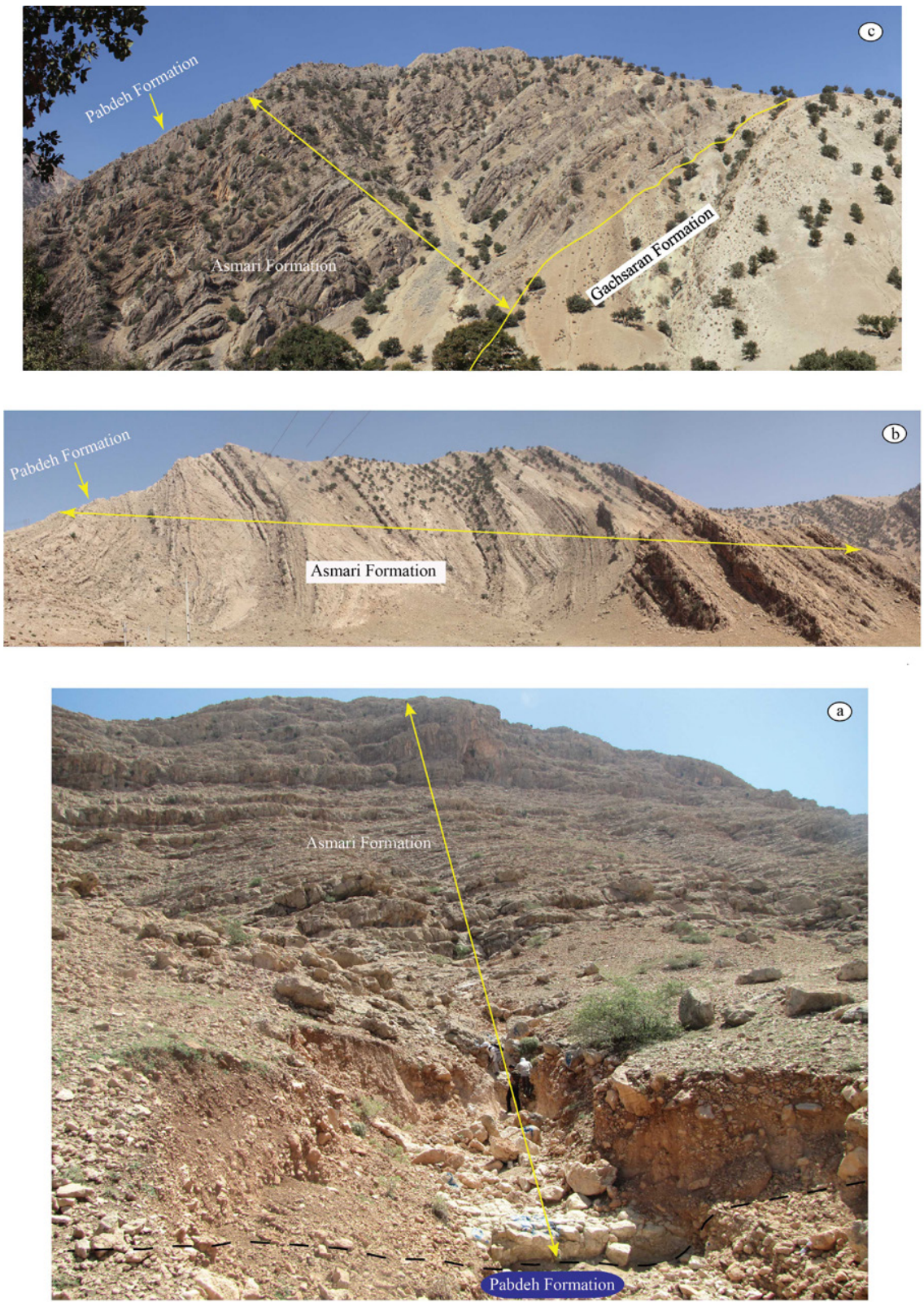

Figure 5 General view of studied sections (a: Kuh Shur; b. Kuh-e Bad and c. Gharibi Ha), view toward north and southeast. 
Table 3. Biozonation of the Asmari Formation in this study.

\begin{tabular}{|c|c|c|c|c|c|}
\hline Stage & No. & Assemblage Zone & Ma. & Location & $\begin{array}{l}\text { SBZ (Cahuzac and } \\
\text { Poignant, 1997) }\end{array}$ \\
\hline Burdigalian & 5 & $\begin{array}{l}\text { Globigerina } \text { spp. } \\
\text { Borelis melo curdica }- \text { Borelis melo melo } \\
\text { Dendritina rangi }+ \text { Meandropdina } \text { spp. }+ \text { Spirolina } \text { sp. }+ \text { polymorphinids }+ \\
\text { Discorbis } \text { sp. }+ \text { small peneroplids }+ \text { Peneroplis evolutus }+ \text { miliolids }\end{array}$ & $18.2-20.2$ & $\begin{array}{l}\text { Halayjan, Kuh Shur, Kuh-e Bad, } \\
\text { Gharibi Ha }\end{array}$ & SBZ 25 \\
\hline Aquitanian & 3 & $\begin{array}{l}\text { Miogypsina }- \text { Elaphidium sp. } 14+\text { Peneroplis farsensis } \\
\begin{array}{l}\text { Miogypsina } \text { spp. }+ \text { Elphidium } \text { sp. } 14+\text { Peneroplis farsensis }+ \text { Favreina } \\
\text { asmaricus }\end{array}\end{array}$ & $20.2-23$ & $\begin{array}{l}\text { Halayjan, Kuh Shur, Kuh-e Bad, } \\
\text { Gharibi Ha }\end{array}$ & SBZ 24 \\
\hline Chattian & 1 & $\begin{array}{l}\text { Archaias asmaricus - Archaias hensoi-Miogypsinoides complanatus } \\
\text { Archaias asmaricus - Archaias hensoi - Miogypsinoides complanatus }+ \\
\text { Spiroclypeus blankenhorni } \\
\text { Lepidocyclina - Operculina - Ditrupa } \\
\text { Eulepidina dilatata }+ \text { Eulepidina elephantina }+ \text { Nephrolepidina tournoueri }+ \\
\text { Operculina companata }+ \text { Spiroclypeus blankenhorni + Heterostegina costata }\end{array}$ & $23-28.2$ & $\begin{array}{l}\text { Kuh-e Bad, Gharibi Ha } \\
\text { Halayjan, Kuh Shur, Kuh-e Bad, } \\
\text { Gharibi Ha }\end{array}$ & SBZ 23 \\
\hline
\end{tabular}

trotrillina sp., Peneroplis farsensis, Peneroplis evolutus, Peneroplis thomasi, Peneroplis sp., Miogypsina irregularis, Miogypsina sp., Miogypsinoides sp., Elphidium sp.14, Elphidium sp. 1, Dendritina rangi, Meandropsina iranica, Meandropsina sp., Favreina asmaricus (Figures 12 and 13) and represents the Miogypsina-Elphidium sp.14Peneroplis farsensis Assemblage Zone of Laursen et al. (2009) and Van Buchem et al. (2010), and to the SBZ 24 of Cahuzac and Poignant (1997). This zone is restricted to Aquitanian.

\subsection{ASSEMBLAGE 4}

This assemblage is recorded in all sections. The most important fauna are: Borelis melo curdica, Borelis melo melo, Borelis sp., Meandropsina iranica, Meandropsina anahensis, Meandropsina sp., Austrotrillina sp., Dendritina rangi, Peneroplis farsensis, Peneroplis sp., Peneroplis evolutus, Elphidium sp.14, Elphidium sp.1, Miogypsina sp., Miogypsinoides sp., Miogypsinoides cf. dehaarti, Amphistegina sp., Operculina complanata, Operculina sp., Globigerina spp., Globigerinoides spp. (Figures 12 and 13). This zone is restricted to the Burdigalian based on the first appearance of Borelis melo curdica, Borelis melo melo (Cahuzac and Poignant, 1997; Laursen et al., 2009; Van Buchem et al., 2010). Although the presence of Miogypsinoides has been reported by Adams and Bourgeois (1967) in Burdigalian time, it is not reported in this time in the recent regional biostratigraphic study of the Asmari Formation introduced by Laursen et al. (2009) and Van Buchem et al. (2010). In this study, we have reported abundant occurrences of this genus (Miogypsinoides) in the study area during the Burdigalian.

\subsection{ASSEMBLAGE 5}

This assemblage occurs from 344 to $415 \mathrm{~m}$ of the Asmari Formation, only in Gharibi Ha section, and consists of Globorotalia obesa, Globigerina praebulloides, Globigerinoides immaturus, Globigerinoides trilobus, Globigerinoides diminutus, Catapsydrax sp., Globigerinoides spp. (Figure 13). This assemblage overlies $78 \mathrm{~m}$ shallower carbonates of Burdigalian age. The top of this assemblage is marked by anhydrite deposits of the base of the Gachsaran Formation. Globigerina spp.-Turborotalia cerroazulensis-Hantkenina Assemblage Zone was introduced by Laursen et al. (2009) (Table 2). The age of this Assemblage Zone is Late Eocene-Early Oligocene. However, Wynd (1965) introduced Globigerina spp. Assemblage Zone (Table 1) from different intervals of the Asmari Formation in different localities in the Zagros Basin. The age of this zone was considered Late Eocene--Oligocene-Early Miocene based on its relationship to the underlying and overlying sediments. We recorded abundance planktonic foraminifera in Gharibi Ha section from above the Borelis melo curdica-Borelis melo melo Assemblage Zone. The age of this Assemblage Zone is considered Burdigalian based on its planktonic 


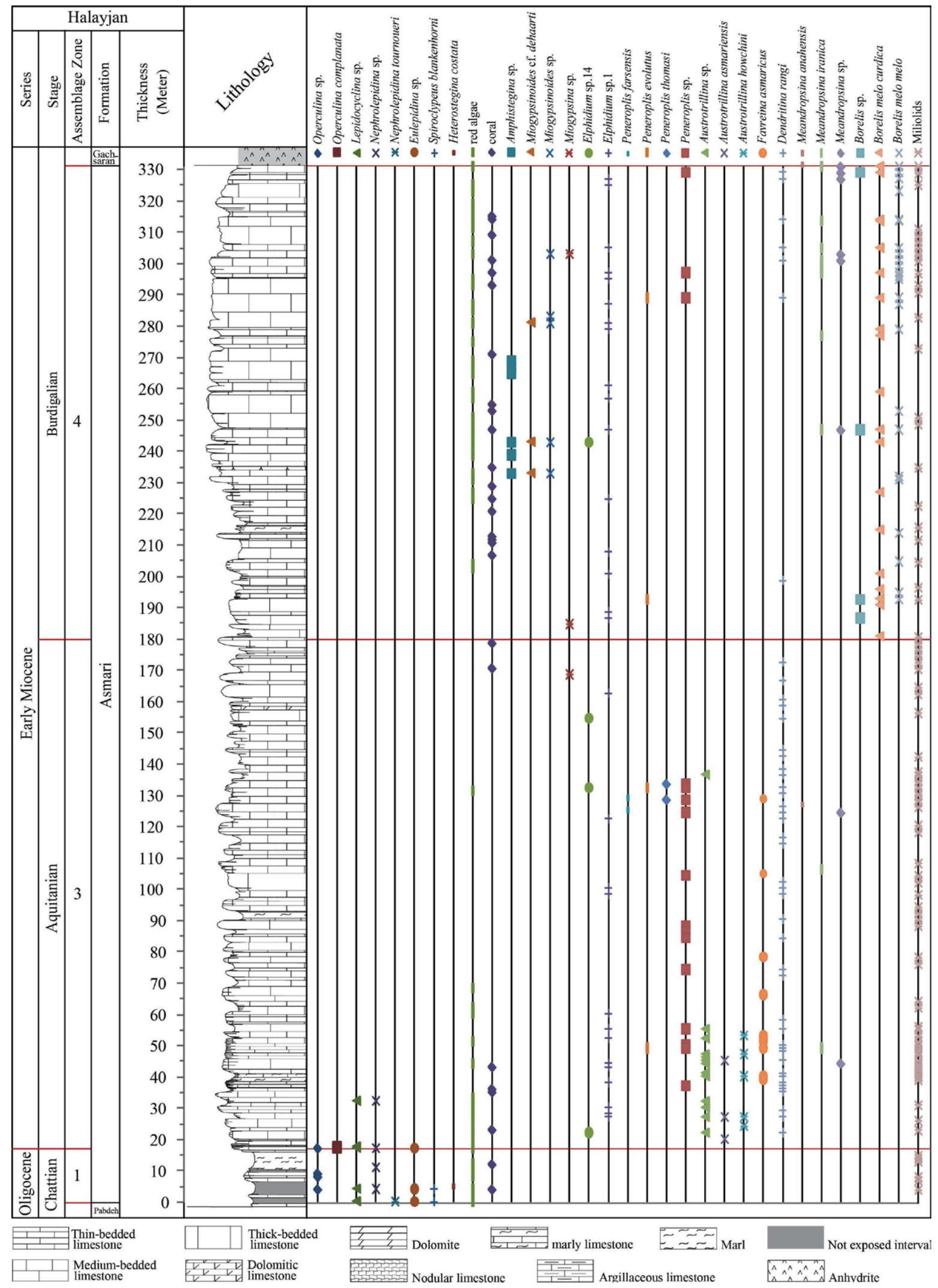

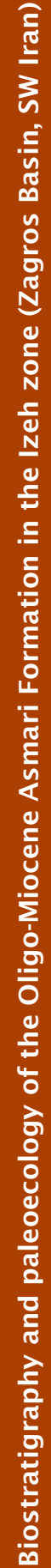




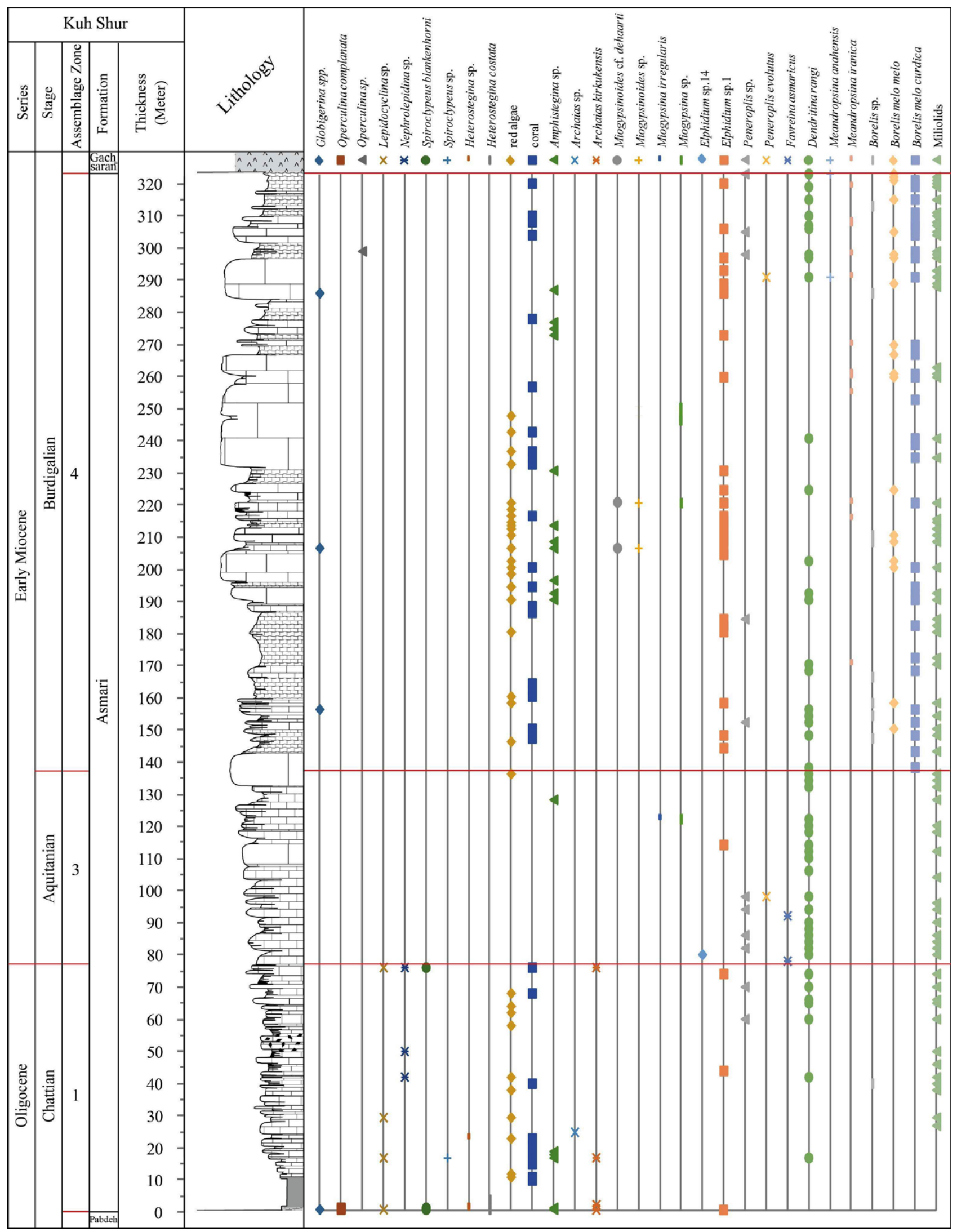

Figure 7 Biostratigraphy of the Asmari Formation at the Kuh Shur section (see Figure 6 for legend). 


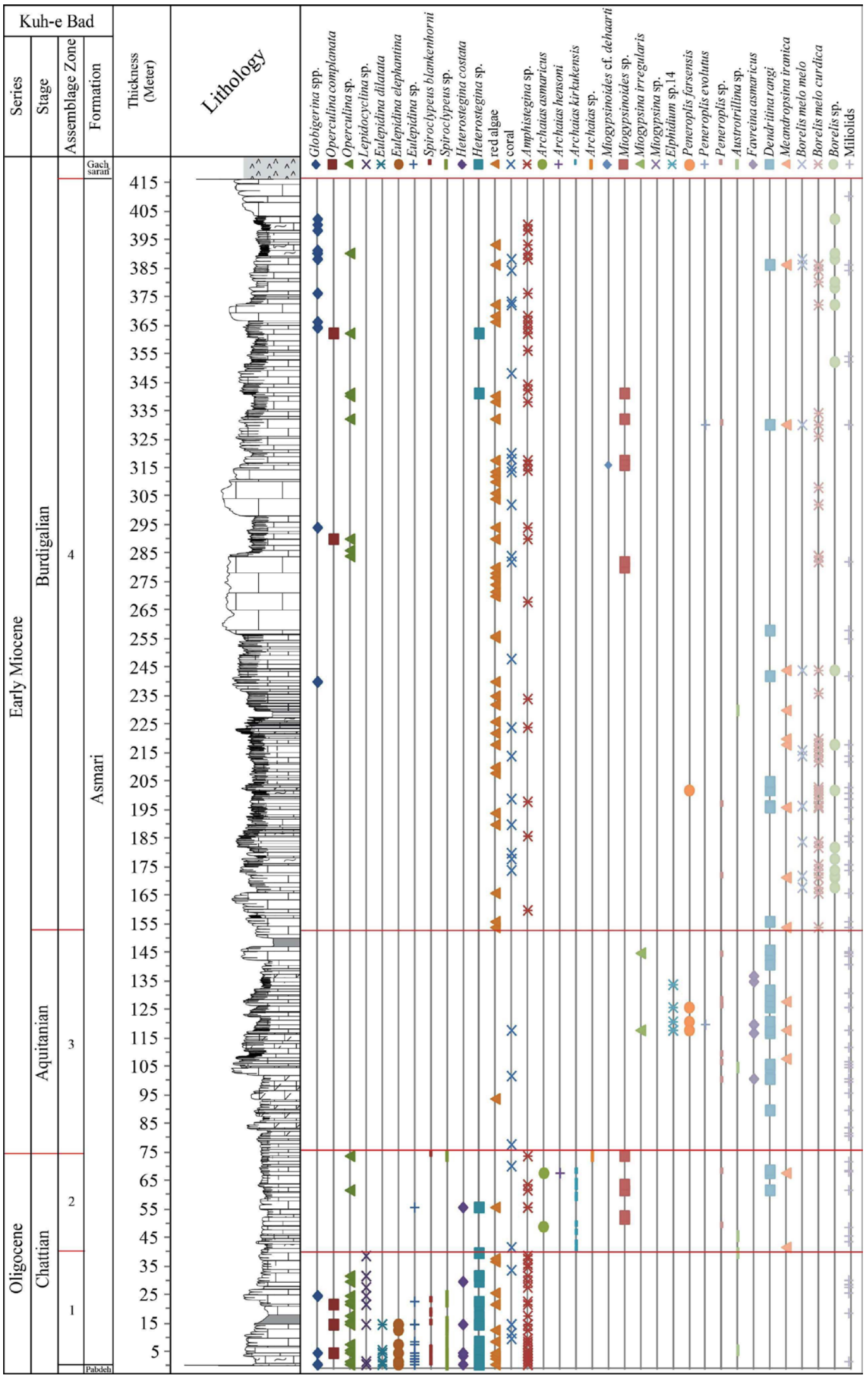




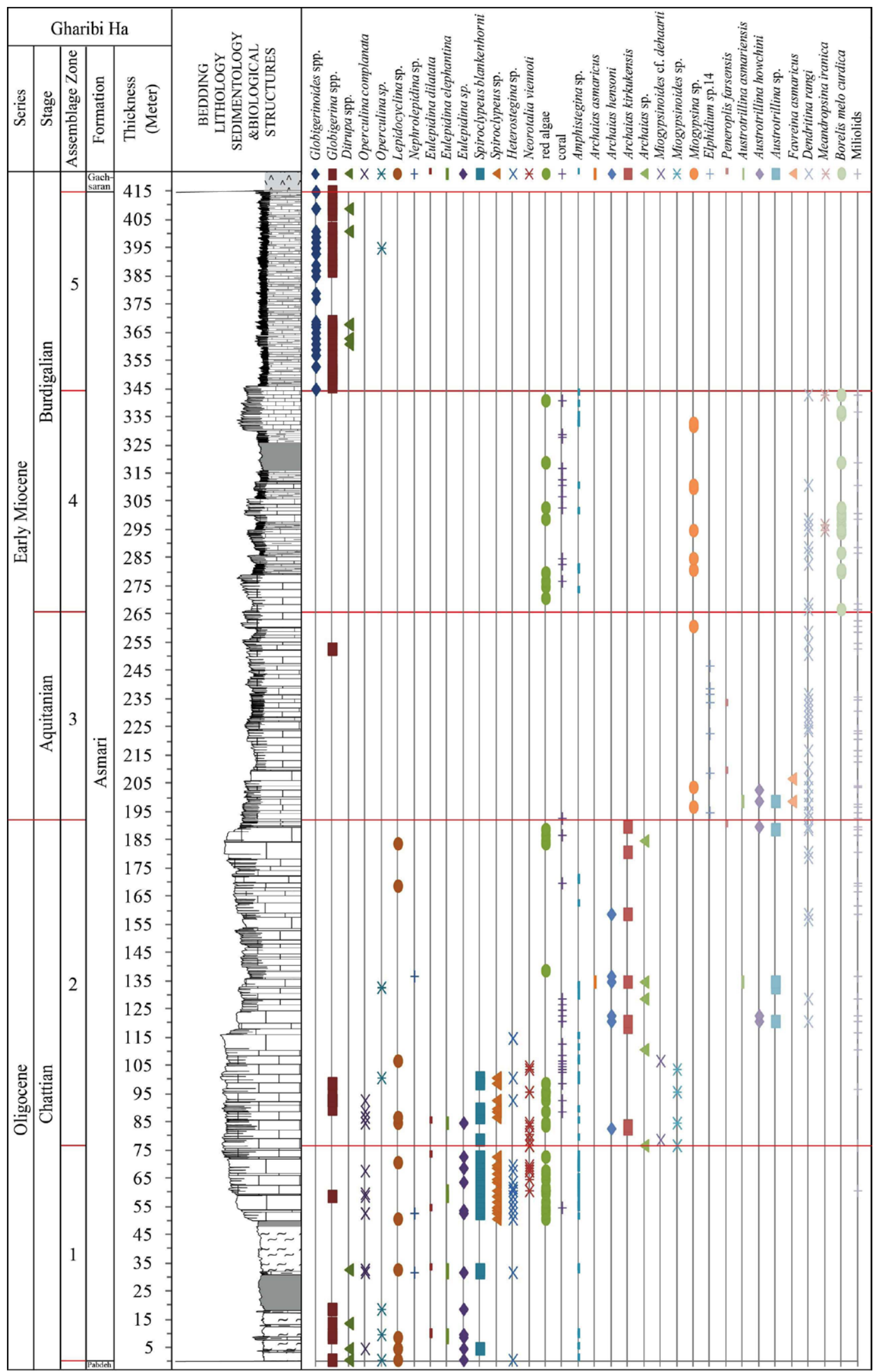

Figure 9 Biostratigraphy of the Asmari Formation at the Gharibi Ha section (see Figure 6 for legend). 


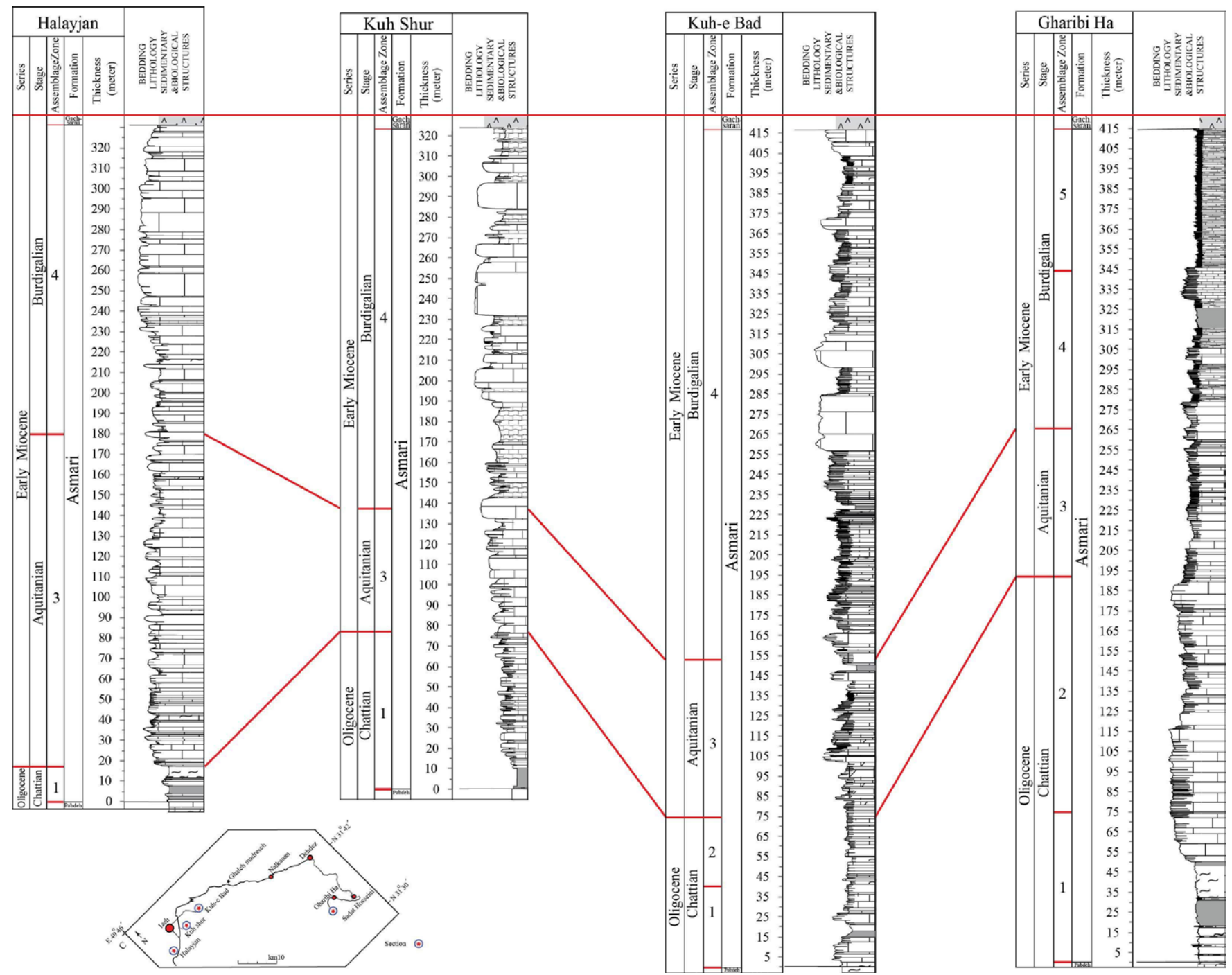

Figure 10 Time correlation of the Asmari Formation between the Halayjan, Kuh Shur, Kuh-e Bad and Gharibi Ha sections (see Figure 6 for legend).

foraminifera (Iaccarino et al., 2005) and underling Burdigalian shallow carbonate sediments.

\section{Paleoecological interpretation}

Paleoecology of Oligocene and Miocene carbonate platforms are studied by many authors with different points of view (e.g., Hallock and Glenn, 1986; Hottinger, 1997; Pedley, 1998; Geel, 2000; Pomar, 2001; Romero et al., 2002; Beavington-Penney and Racey, 2004; Cosovic et al., 2004; Pomar et al., 2004; Pomar and Hallock, 2008; Brandano et al., 2009a, b; Bassi and Nebelsick, 2010; Flügel, 2010; Pomar et al., 2012). In this study the most significant paleoecological elements such as salinity, light penetration, nutrients, temperature and water depth are discussed in detail.

\subsection{CHATTIAN}

In the Chattian succession of the studied area the most significant and dominant biogenic components are coralline red algae; large, flat and perforate benthic foraminifera (Operculina, Heterostegina, Eulepidina, Nephrolepidina, Spiroclypeus, Amphistegina 


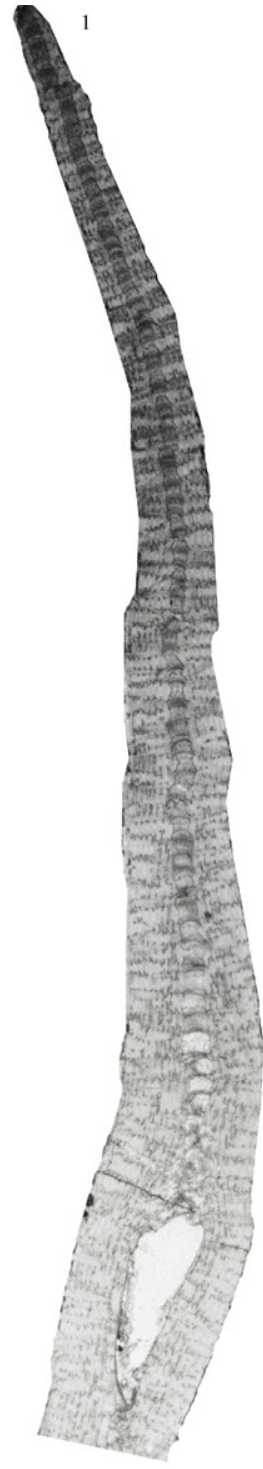

$1 \mathrm{~mm}$
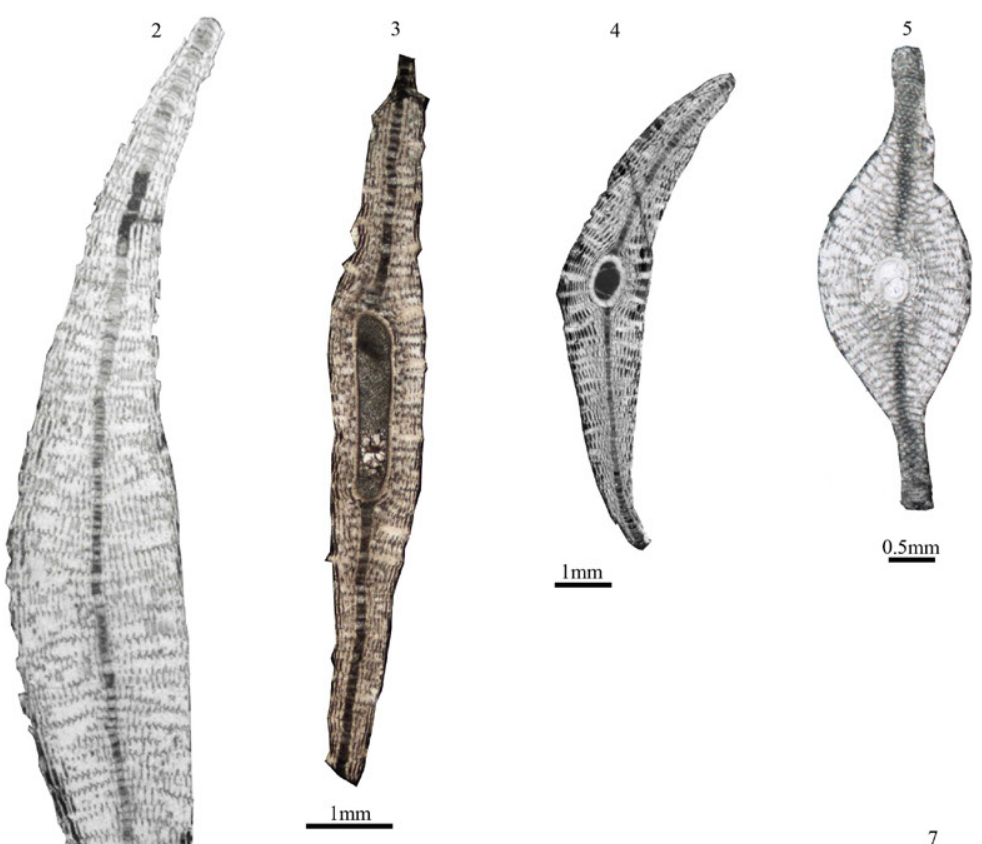

$\underline{\mathrm{mm}}$
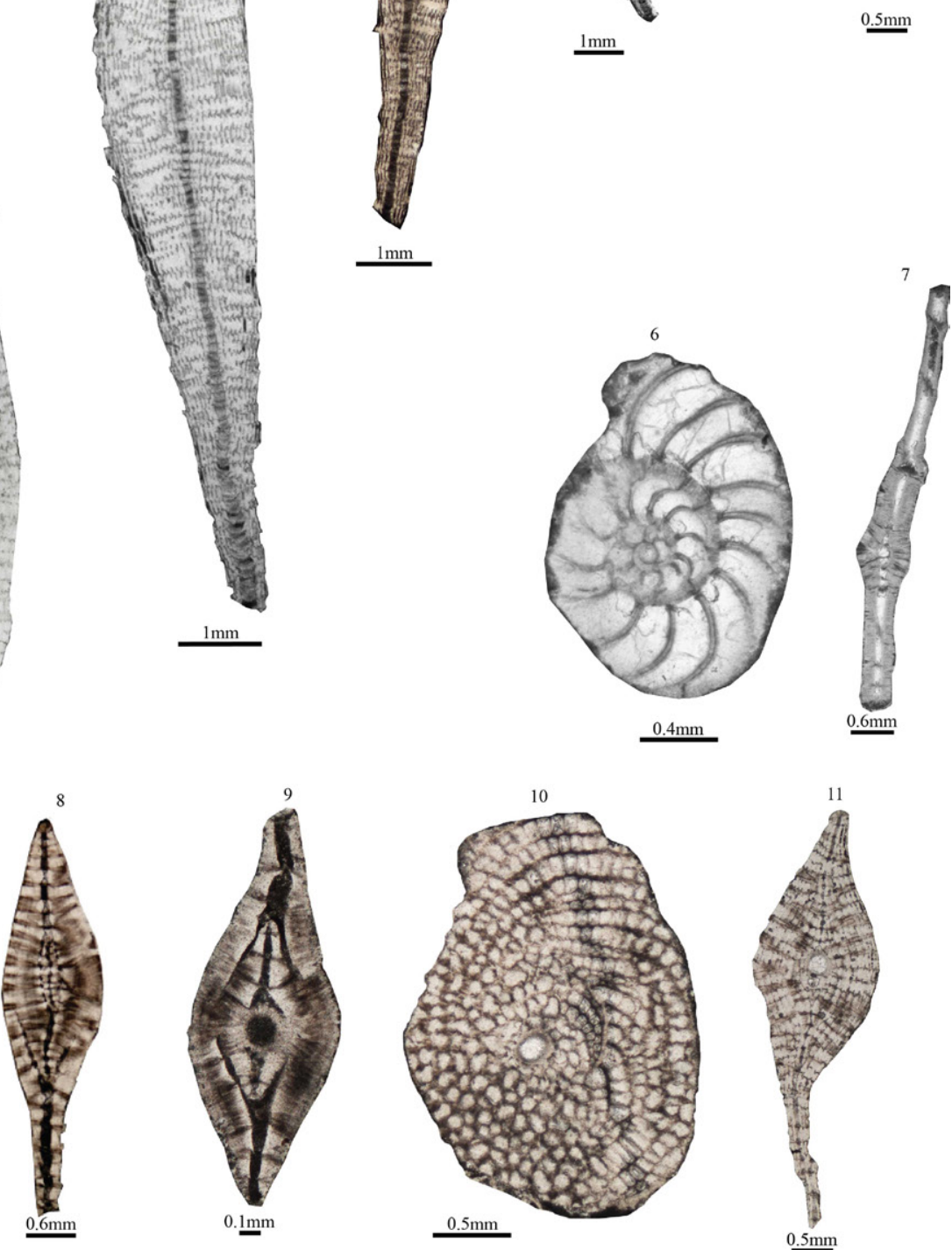

Figure 11 Photomicrograph of some selected fauna of the Asmari Formation in the studied sections. 1) Eulepidina elephantina (Lemoine and Douville, 1904), axial section, sample number K2; 2) Eulepidina sp., subaxial section, sample number K15; 3) Eulepidina dilatata (Michelotti, 1861), axial section, sample number G8; 4) Eulepidina dilatata, axial section, sample number K3; 5) Nephrolepidina tournoueri (Lemoine and Douville, 1904), axial section, sample number H0; 6) Operculina sp., subequatorial section, sample number H17.5; 7) Operculina complanata (Defrance, 1822), axial section, sample number K22; 8) Heterostegina sp., subaxial section, sample number G54; 9) Heterostegina sp., axial section, sample number G50; 10) Spiroclypeus blankenhorni (Henson, 1937), equatorial section, sample number G61; 11) Spiroclypeus blankenhorni (Henson, 1937), axial section, sample number G67. 

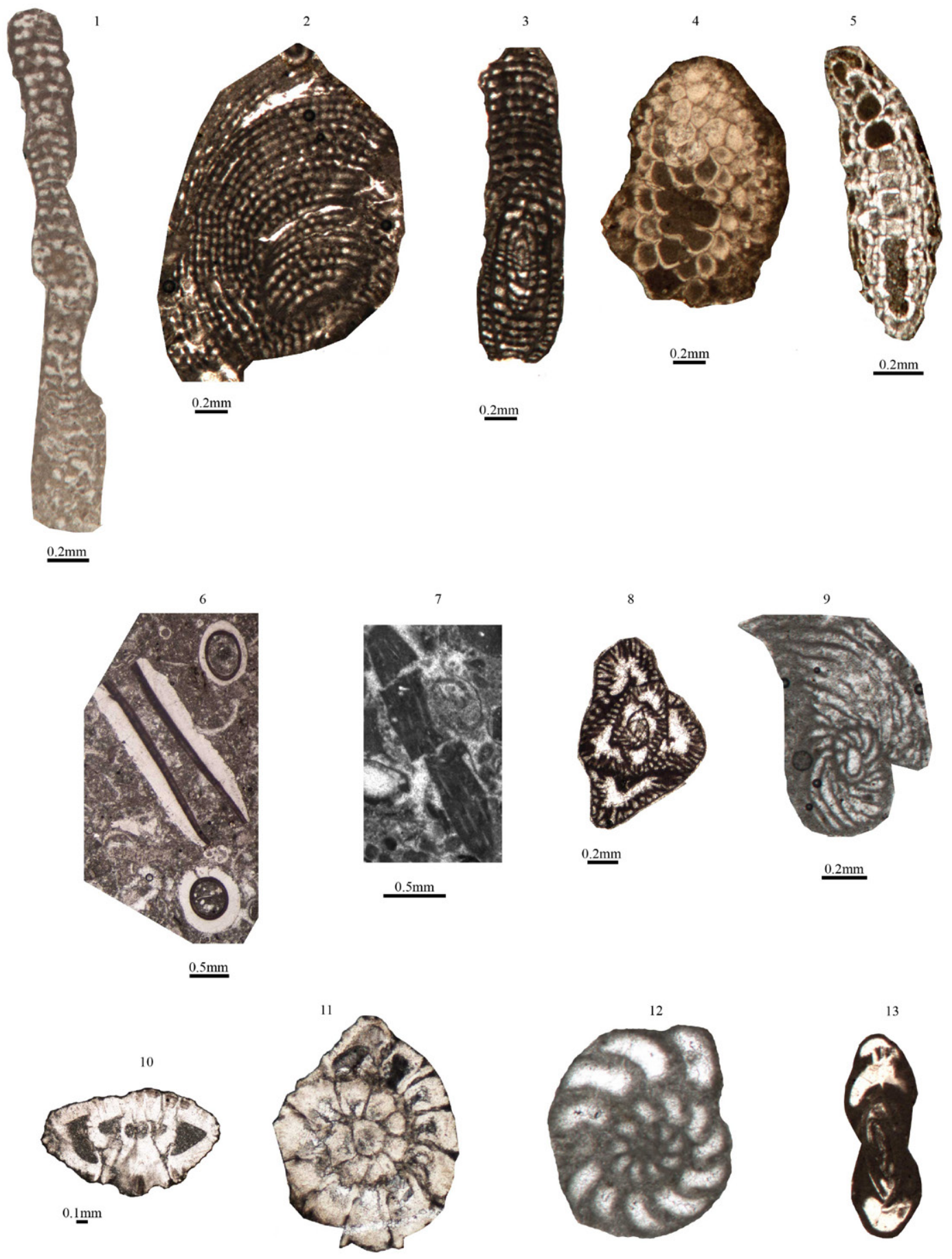

$0.1 \mathrm{~mm}$

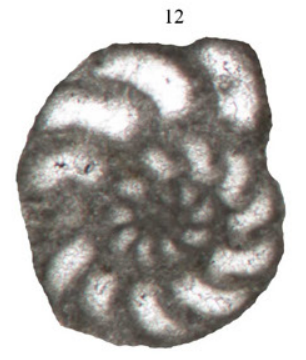

$\underline{0.2 \mathrm{~mm}}$

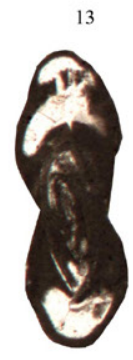

$\underline{0.2 \mathrm{~mm}}$

Figure 12 Photomicrograph of some selected fauna and other elements of the Asmari Formation in the studied sections. 1) Archaias hensoni (Smout and Eames, 1958), subaxial section, sample number K68; 2) Archaias sp., subequatorial section, sample number K68; 3) Archaias kirkukensis (Henson, 1950), subaxial section, sample number K68; 4) Miogypsina cf. globulina (Michelotti, 1841), subequatorial section, sample number K118; 5) Miogypsina cf. irregularis (Michelotti, 1841), axial section, sample number K145; 6) Ditrupa sp., sample number G367; 7) Favreina asmaricus (Elliott, 1962), oblique section, sample Number K120; 8) Austrotrillina howchini (Schlumberger, 1893), equatorial section, sample number H47; 9) Peneroplis sp., equatorial section, sample number H192; 10) Neorotalia viennoti (Greig, 1935), axial section, sample number G84; 11) Neorotalia viennoti (Greig, 1935), subequatorial section, sample number G60; 12) Dendritina rangi (d’Orbigny emend. Fornasini, 1904), subequatorial section, sample number K141; 13) Dendritina rangi (d’Orbigny emend. Fornasini, 1904), subaxial section, sample number K68. 

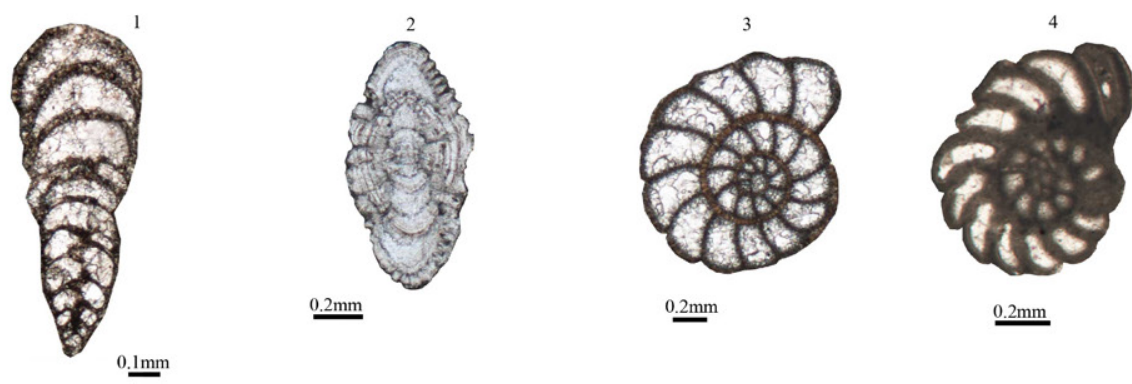

$\underline{0.2 \mathrm{~mm}}$
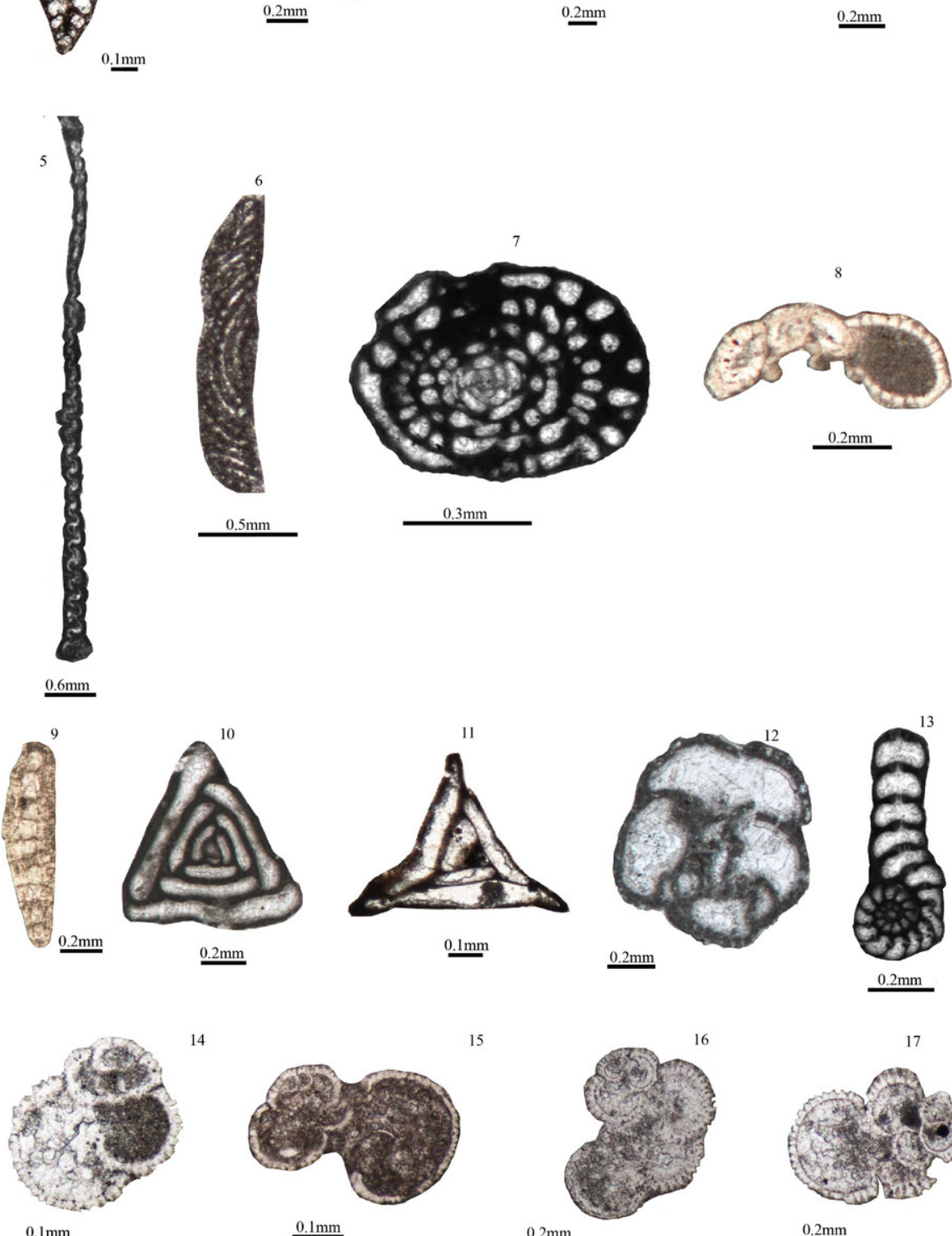

15
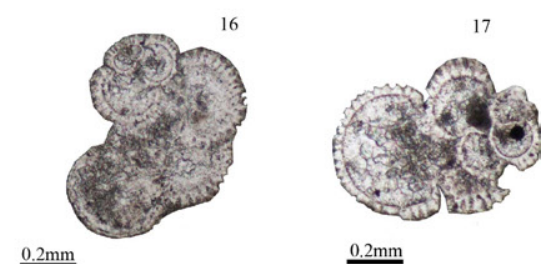

Figure 13 Photomicrograph of some selected fauna of the Asmari Formation in the studied sections. 1) Bigenerina sp., Longitudinal section, sample number G288; 2) Elphidium sp.14, axial section, sample number G238; 3) Elphidium sp.1, equatorial section, sample number G274; 4) Peneroplis cf. farsensis (Henson, 1950), equatorial section, sample number K69; 5) Meandropsina iranica (Henson, 1950), subaxial section, sample number H276; 6) Meandropsina anahensis (Henson, 1950), oblique equatorial section, sample number G128; 7) Borelis melo curdica (Reichel, 1937), axial section, sample number K171.5; 8) Discorbis sp., axial section, sample number H1 86; 9) Miogypsinoides sp., axial section, sample number K282; 10) Triloculina trigonula (Lamarck, 1804), equatorial section, sample number $\mathrm{K} 121$; 11) Triloculina tricarinata (d’Orbigny, 1826), equatorial section, sample number G312; 12) Valvulinid sp., Longitudinal section, sample number H72; 13) Spiroloculina cf. cylindracea (Henson, 1950), equatorial section, sample number KS41; 14) Globigerina sp., axial section, sample number G396; 15) Globigerinoides trilobus (Reuss, 1850), axial section, sample number G367; 16) Globigerinoides subqudratus (Broennimann, 1954), axial section, sample number G386; 17) Globigerinoides diminutus (Bolli, 1957), axial section, sample number G414. 
and Lepidocyclina); and imperforate foraminifera (Archaias, Peneroplis, Dendritina). Other skeletal grains consist of echinoid, gastropod, bryozoan and bivalve fragments (Table 4). Accordingly, the paleoecological conditions of the Asmari Formation during the Chattian could be interpreted as follows:

Nummulitids, lepidocyclinids and red algae thrived in oligophotic to mesophotic mid-ramp environments (Kuh-e Bad and Gharibi Ha) preferably at water depths that ranged from 40 to $80 \mathrm{~m}$ (Bosence, 1983; Hottinger, 1997; Beavington-Penney and Racey, 2004).

Occurrence of large perforate benthic foraminifera (Eulepidina, Heterostegina, Neorotalia, Amphistegina), coralline red algae (Lithophyllum and Lithothamnion), imperforate foraminifera (Archaias, Peneroplis, Dendritina, Austrotrillina, miliolids) and molluscs (oysters, other bivalves, gastropods) in Kuh Shur, Kuh-e Bad and Gharibi Ha sections indicate normal to higher sea water salinity in inner ramp setting (Flügel, 2010; Allahkarampour Dill et al., 2012) and could be consider as foralgal to foramol association (Wilson and Vecsei, 2005), (Figure 14) (Table 4).

The carbonates of the Asmari Formation in the study area were replaced by basinal marl and shale of the Pabdeh Formation towards the center of interashelf (toward the south). In the studied sec- tions a major part of carbonate of the Asmari Formation (Chattian in age) in the Gharibi Ha and Kuh-e Bad sections is replaced by basinal marl and shale of the Pabdeh Formation in Halayjan section.

\subsection{AQUITANIAN}

The Aquitanian is characterized by abundant imperforate benthic foraminifera such as Dendritina, Peneroplis, Meandropsina, Austrotrillina and miliolids. Perforate foraminifera such as Miogypsina, Miogypsinoides and Elphidium are also present as subordinate components. Mollusks and echinoids are also present. The Aquitanian biota of the studied area represents a foramol assemblage (Lees and Buller, 1972) (Figure 15) (Table 4). These foraminifera indicate a low energy and hypersaline condition and interpreted as a semi-restricted lagoon setting (inner ramp) (Wilson, 1975; Geel, 2000; Corda and Brandano, 2003; Bassi et al., 2007; Flügel, 2010).

This biotic association indicates a deposition within the photic zone, in a sea-grass-dominated environment as suggested by the presence of epiphytic porcellaneous foraminifera such as Peneroplis and miliolids (Wilson, 1975; Langer, 1993; Beavington-Penney and Racey, 2004; Reich et al., 2015). Further evidence for sea grass can be

Table 4. Vertical distribution of faunal composition, paleoecological elements, grain association and depositional environment of the Asmari Formation in the study area.

\begin{tabular}{|c|c|c|c|c|c|c|}
\hline Age & Component & Salinity & Nutrient & $\begin{array}{c}\text { Grain } \\
\text { association }\end{array}$ & Environment & Light \\
\hline \multirow{2}{*}{ 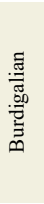 } & $\begin{array}{l}\text { Meandropsina, Dendritina, Elphidium, Borelis, molluscs, } \\
\text { echinoids,coral, coralline red algae, miliolids } \\
\text { Subordinate biota: Operculina, Amphistegina,Miogypsinoides, } \\
\text { Miogypsina }\end{array}$ & Close to normal marine & Oligo-Mesotrophic & $\begin{array}{c}\text { Foralgal to } \\
\text { foramol }\end{array}$ & Mid-Inner ramp & Mesophotic to euphotic \\
\hline & $\begin{array}{l}\text { + Minor planktonic foraminifera at Kuh-e Bad section } \\
\text { + Abundant planktonic foraminifera at Gharibi Ha section }\end{array}$ & Normal marine & Oligotrophic & Nanofor & Outer ramp & Aphotic \\
\hline 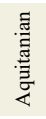 & $\begin{array}{l}\text { Dendritina, Peneroplis, Meandropsina, Austrotrillina, miliolids, } \\
\text { molluscs, echinoids } \\
\text { Subordinate biota: Miogypsina and Elphidium } \\
\text { +Favreina asmaricus }\end{array}$ & $\begin{array}{c}\text { Slightly saline to } \\
\text { normal marine } \\
\text { Hypersaline }\end{array}$ & Oligo-Mesotrophic & Foramol & Inner ramp & Euphotic \\
\hline 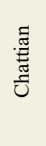 & $\begin{array}{l}\text { corallin red algae and large benthic foraminifera ( Opeerculina, } \\
\text { Heterostegina, Eulepidina, Nephrolepidina, Spiroclypeus, } \\
\text { Amphistegina, Lepidocyclina, Neorotalia, Archaias, Peneroplis } \\
\text { and Dendritina), mollusc } \\
\text { Subordinate biota: coral, miliolids, Austrotrillina, }\end{array}$ & $\begin{array}{l}\text { Normal marine to } \\
\text { Slightly saline }\end{array}$ & Oligo-Mesotrophic & $\begin{array}{c}\text { Foralgal to } \\
\text { foramol }\end{array}$ & Mid-Inner ramp & $\begin{array}{c}\text { Oligo-Mesophotic to } \\
\text { euphotic }\end{array}$ \\
\hline
\end{tabular}




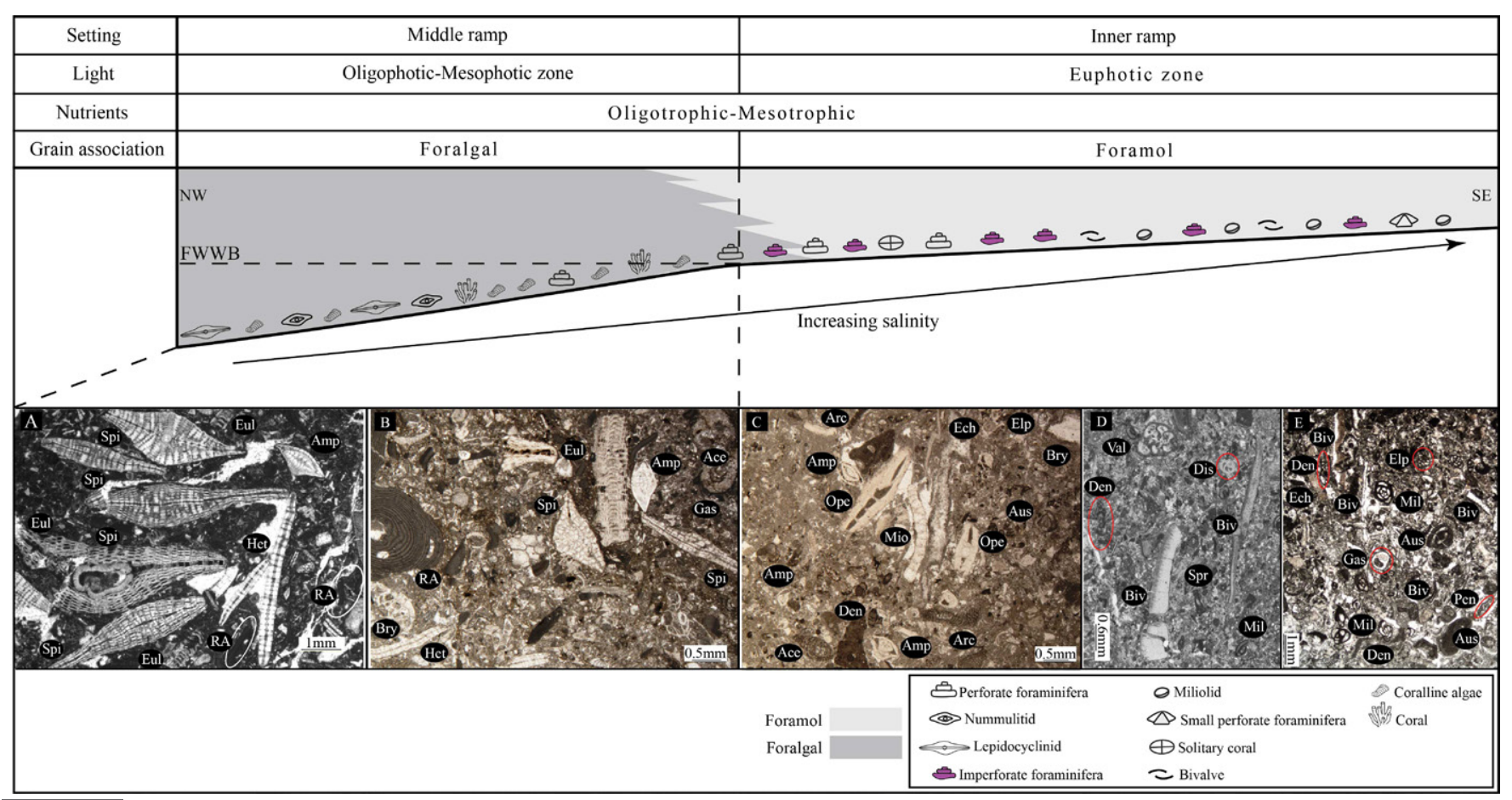

Figure 14 Sedimentary and paleoecological profile of the Asmari Formation during the Chattian time. A) floatstone to rudstone with abundant LBF (specially Spiroclypeus); B) packstone with abundant LBF and red-algal fragments; C) wackestone to packstone with perforate and imperforate benthic foraminifera; D) wackestone to packstone with high diversity of imperforate benthic foraminifera; E) packstone to grainstone with low diversity of imperforate foraminifera (mostly Dendritina), Amp: Amphistegina, Arc: Archaias, Aus: Austrotrillina, Biv: Bivalve, Bry: Bryozoan, Den: Dendritina, Dis: Discorbis, Ech: Echinoid fragment, Elp: Elphidium, Eul: Eulepidina, Gas: Gastropod, Het: Heterostegina, Mil: Miliolids, Ope: Operculina, RA. non-articulated red-algal fragments, Spi: Spiroclypeus, Spr: Spiroloculina, Val: Valvulinid.

given by the poorly sorted and micrite-rich textures and absence of sedimentary structures. The associated fauna (Peneroplis, Borelis, discorbids and thick samples of Amphistegina) are also typical for seagrass meadows (Murray, 1973; Brasier, 1975; Beavington-Penney and Racey, 2004; Brandano et al., 2009a; Reuter et al., 2010; Pomar et al., 2014). One of the most important and excellent markers for the Aquitanian is Favreina asmaricus (coprolitic facies) (Figure 15) (Table 4) with occurrences related to the particular environmental condition (isolated hypersaline basins for part of the time) (Laursen et al., 2009; Van Buchem et al., 2010). In the more saline interval Favreina asmaricus is common (Mossadegh et al., 2009). The presence of porcellaneous benthic foraminifera with Favreina asmaricus, coralline algae, coral, bryozoa and echinoderm fragments are common in lower parts of the Aquitanian sediments, especially in Halay- jan section. Favreina asmaricus is rare in Kuh Shur, Kuh-e Bad and Gharibi Ha sections which are situated in shallower parts of the Asmari intrashelf basin.

The Favreina limestone is a well known facies of intrashelf margin of the Aquitanian. It has been interpreted as restricted condition of interashelf basin (Van Buchem et al., 2010).

\subsection{BURDIGALIAN}

In the study area, the common biota of the Burdigalian are coral, coralline algae, Amphistegina, Miogypsinoides, Meandropsina, Elphidium, Borelis, Dendritina, Peneroplis, miliolids and mollusc debris (Table 4). A similar assemblage was reported from the inner ramp of the Miocene sediments of the Central Apennines (Corda and Brandano, 2003) and from the Early Oligocene deposits of 


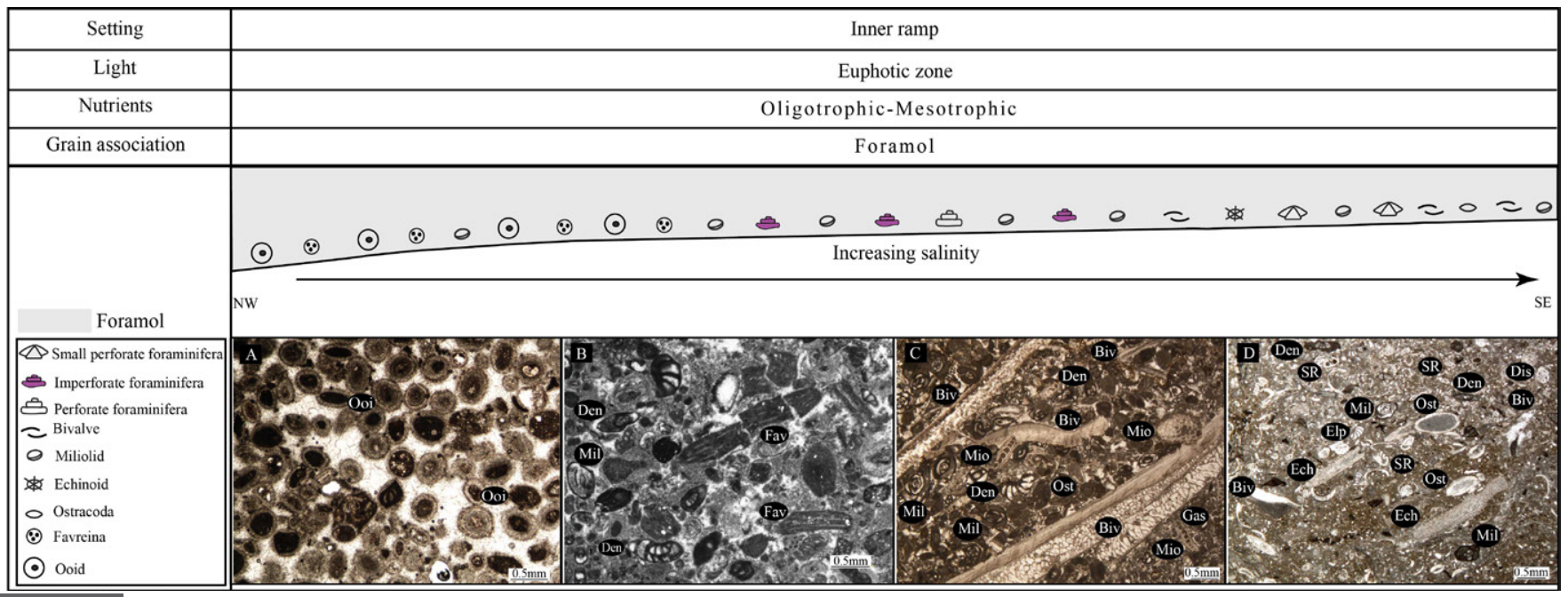

Figure 15 Sedimentary and paleoecological profile of the Asmari Formation during the Aquitanian time. A) Ooid grainstone; B) packstone to grainstone dominated with non-skeletal grains (Ooid and Favreina); C) packstone to grainstone with imperforate benthic foraminifera; D) wackestone to packstone with small benthic foraminifera and Echinoid fragments; Biv. Bivalve fragment; Den. Dendritina; Dis: Discorbis, Ech. Echinoid fragment; Elp. Elphidium; Fav. Favreina; Gas. Gastropod; Mil. Miliolids; Mio: Miogypsinoides, Ooi. Ooid; Ost. Ostracod; Pen. Peneroplis; SR. Small rotalids.

the Lower Inn Valley (Nebelsick et al., 2001). The abundance of larger benthic foraminifera (Borelis, Peneroplis, Dendritina, Heterostegina, Operculina) and zooxanthellate corals indicate mesophothic to euphotic condition (Halfar et al., 2004; Pomar et al., 2004; Pomar and Hallock, 2008; Brandano et al., 2009b; Mazzucchi and Tomassetti, 2011; Tomassetti and Brandano, 2013). During the Burdigalian a slightly restricted lagoon became established over the entire width of the platform in the SW (e.g. Dezful Embayment) characterized by proliferation of imperforate foraminifera (Rahmani et al., 2009).

At Kuh-e Bad section, planktonic foraminifera (rare), coral, corallinacean algae, Heterostegina and Operculina are also present in the Burdigalian assemblage (Table 4). Towards the east of studied area (figures $1 \mathrm{C}$ and 10) in Gharibi Ha section, planktonic foraminifera facies is more common in the upper part of the Burdigalian. These faunal associations represent a nannofor assemblage (Lees and Buller, 1972) (Table 4). The nannofor (aphotic zone-outer shelf) association occurred in a deeper water depositional setting. The existence of abundant planktonic foraminifera indicates that the sediment of the upper part of the Burdi- galian was deposited in deeper-water environment in Gharibi Ha section (Figures 16 and 17).

\section{Discussion}

Our detailed analysis of the stratigraphy and paleoecology show that the Asmari Formation was deposited on a carbonate ramp in tropical to subtropical latitudes $\left(10^{\circ}\right.$ to $\left.30^{\circ}\right)$ (Vaziri-Moghaddam et al., 2006; Heydari, 2008; Allahkarampour Dill et al., 2010; Vaziri-Moghaddam et al., 2010; Shabafrooz et al., 2015a, b). The differentiation between non-tropical and tropical carbonates is mainly based on analysis of skeletal components (Lees and Buller, 1972; Carannante et al., 1988; Nelson, 1988). The foraminiferal associations such as Dendritina, Archaias, Borelis, Spiroclypeus, Lepidocyclina, Neorotalia, and Amphistegina within the Asmari Formation suggest that carbonate sedimentation took place in tropical to subtropical latitudes. The symbiont bearing larger foraminifera are known to thrive in tropical waters (Langer and Hottinger, 2000). According to Heydari (2008) the Zagros Basin was located close to $30^{\circ} \mathrm{N}$ during the Oligocene-Miocene. This idea suggests that carbonate 
sedimentation of the Asmari Formation took place in tropical to subtropical waters.

Zooxanthellate corals and large benthic foraminifera are the most successful shallow, benthic carbonate producers in clear, tropical-subtropical oceanic waters (Hallock, 2001). Zooxanthellate corals and the LBF (Borelis, Archaias, Peneroplis, Lepidocyclina) assemblages of the Asmari Formation

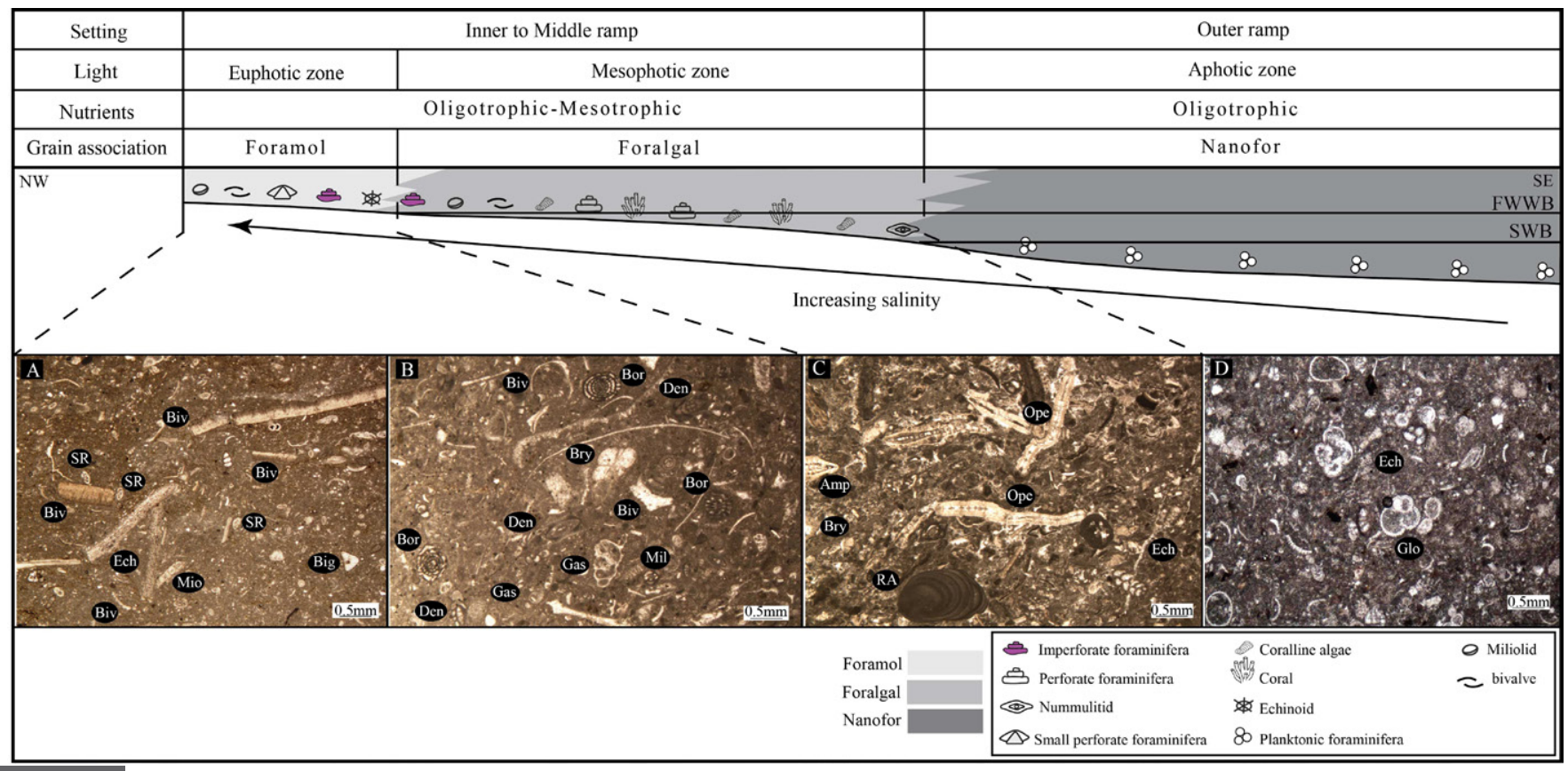

Figure 16 Sedimentary and paleoecological profile of the Asmari Formation during the Burdigalian time. A) wackestone with small benthic foraminifera and Echinoid fragments; B) wackestone to packstone with high diversity of imperforate foraminifera; C) packstone with perforate benthic foraminifera and red-algal fragments; D) packstone dominated with planktonic foraminifera and Echinoid fragments; Biv: Bivalve fragment, Bor: Borelis, Bry: Bryozoan, Den: Dendritina, Ech: Echinoid fragment, Gas: Gastropod, Glo: Globigerinids, Mea: Meandropsina, Mil: Miliolids, Mio: Miogypsinoides, Ope: Operculina, RA: non-articulated red-algal fragments, SR: Small rotalids.

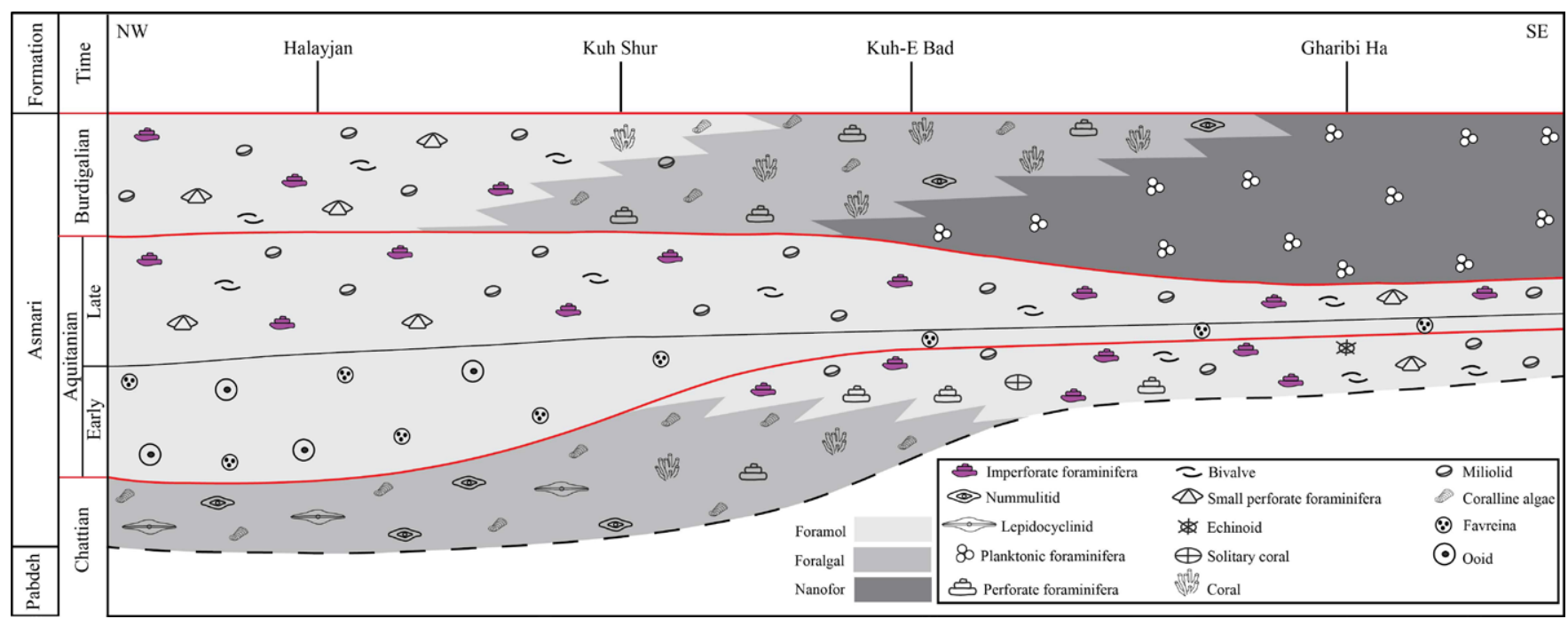

Figure 17 Depositional and paleoecology conceptual model of the Asmari Formation during the Chattian - Burdigalian. 
thrive in oligotrophic to possibly slightly mesotrophic waters (Langer and Hottinger, 2000; Halfar et al., 2004; Pomar et al., 2004; Bassi and Nebelsick, 2010).

Oligotrophic to mesotrophic conditions in the inner ramp setting (Chattian-Burdigalian) lead to the occurrence of larger imperforate foraminifera such as Archaias, Borelis, Peneroplis and Austrotrillina. These porcellaneous larger foraminifera show well lit, highly translucent, shallowest part of the photic zone. Lens shaped rotalids lived in mesophotic conditions in the middle ramp setting (Chattian), and large and flat lepidocyclinid-nummulitids characterizes the sediments of the deeper oligophotic zone in the middle ramp setting (Chattian). These assemblages of benthic foraminifera are not identified in the Kuh Shur and Halayjan sections, because of their deep-seated paleogeographical position during the Chattian (Figure 10). However, the base of the Asmari Formation deposits, from southeast to northwest, becomes younger and diachronous. Consequently, this stepwise younging could be expected in series with basinward progradation of the Asmari Formation over the basinal shale and marl of the Pabdeh Formation. Some of these progradational architectures (e.g. Eshgar and Gurguda clinoforms) have been documented in different parts of the Asmari depositional basin (Van Buchem et al., 2010; Shabafrooz et al., 2015b). During the Chattian the thickness of the Asmari Formation increases from northwest to southeast in the study area. Afterward, during the Aquitanian, the thickest interval of the formation is recorded in the Halayjan section. In the Burdigalian the thickness of the formation increases from the Halayjan section to the Kuh-e Bad and decreases towards the Gharibi Ha section (Figure 10).

The upper part of the Asmari Formation in the Gharibi Ha section (Burdigalian) is characterized by abundance of planktonic Foraminifera. This suggests that deeper-water carbonate (nannofor, oligophotic to aphotic, outer ramp) deposition was active in the Asmari Formation, in the Gharibi Ha section. The planktonic foraminifera documented within the upper part of the Asmari Formation in the Gharibi Ha section also indicate a deposition in the tropical waters under oligotrophic conditions as suggested by the occurrence of Globigerinoides trilobus which proliferate in warm nutrient-poor waters (Tolderlund et al., 1971; Be, 1977; Hemleben et al., 1989). In the light of modern analogues, the occurrence of larger benthic foraminifera and zooxanthellate corals in the geological record is interpreted as photozoan assemblages. Nevertheless, the Asmari Formation is dominated by heterozoan assemblages. Heterozoan carbonates can develop on a carbonate ramp (Carannante et al., 1988; Jones and Desrochers, 1992; Boreen and James, 1995; Feary, 1995; Brachert et al., 1998). The spread of heterozoan assemblages related to the low capacity of corals to thrive in high-light conditions and to form a wave-resistant reef promoted the distribution of heterozoan assemblages (Brandano et al., 2009a; Rahmani et al., 2009; Allahkarampour Dill et al., 2010).

Oligo-Miocene carbonates are extensive throughout SW Iran. The Dill Anticline section (Allahkarampour Dill et al., 2010, 2012) and the Gachsaran and Bibi-Hakimeh oilfields (Shabafrooz et al., 2015b) were selected for comparison with the studied sections. The biotic associations of the mentioned areas are quite similar to those described in the study area. They were deposited on a carbonate ramp dominated by heterozoan skeletal assemblages, in which most benthic carbonate production occurred in inner-to-middle ramp settings. The main producers were larger benthic foraminifera and red algae, but zooxanthellate corals are rare (Allahkarampour Dill et al., 2010, 2012; Shabafrooz et al., 2015b). This biotic association suggests that carbonate sedimentation of the Asmari Formation took place in tropical-subtropical waters under oligotrophic-mesotrophic conditions.

The other examples of the Oligocene shallow-water carbonates have been described in Malta (Brandano et al., 2009a, b) and in northeastern Italy Lessini Shelf Venetian foreland basin (Bassi and Nebelsick, 2010). At these areas rotalids, miliolids and imperforate foraminifera are frequent 
in the inner ramp, while red algae and lepidocyclinids are abundant in the middle ramp. The foraminiferal assemblage of the Asmari Formation shows close affinities to that described by Brandano et al. (2009a) of the Malta carbonate platform. Such assemblages suggest that carbonate sedimentation took place in tropical to sub-tropical waters, under oligotrophic to slightly mesotrophic conditions. In the carbonate platform of the Attard Member (Brandano et al., 2009a, b) and Asmari Formation, zooxanthellate corals did not form a reef framework.

As a result, the lateral facies distribution within the Asmari succession suggests that the sea level in the Chattian was relatively shallow, but deepened toward the NW region. These observations indicate that the Chattian to Aquitanian was a time of relative tectonic quiescence in this area. The lateral distribution of facies during the Late Burdigalian suggests a significant depth range, from the shallowest facies in the NW region to the most distal facies in the SE region. This pattern contrasts with subtle lateral shifts in facies characteristic of the underlying sequence, suggesting increased subsidence during this time in the SE regions (Figure 17). Previous studies (Seyrafian, 2000; Van Buchem et al., 2010) mentioned that in the north Izeh area, the shallow water deposits of the Early Burdigalian are locally overlain by pelagic marls of the Late Burdigalian (e.g. Ghaleh Madreseh section), while in the Chidan section (Figure 1C), coral, corallinacean algae, benthic imperforate and perforate foraminifera were deposited (Van Buchem et al., 2010). The deepening in the north is considered a result of a regional tilting that started in the Late Burdigalian (Van Buchem et al., 2010) (Figure 17).

\section{Conclusion}

In this research based on the micropaleontological analysis of the larger benthic foraminifera and their distribution, five assemblage zones have been recorded. Three assemblages $(1,3,4)$ are present in all sections (Halayjan, Kuh Shur, Kuh-e Bad and Gharibi Ha). Assemblage 2 is recorded in two sections (Kuh-e bad and Gharibi Ha) and assemblage 5 is only occurred in Gharibi Ha section. Assemblages 1 and 2 indicate the Chattian age; assemblage 3 is restricted to the Aquitanian age; and assemblages 4 and 5 suggest the Burdigalian age. According to this study, the age of the Asmari Formation ranges from the Oligocene (Chattian) to Early Miocene (Aquitanian-Burdigalian).

The biotic associations within the Asmari Formation indicate that the lower part of the Asmari Formation (Chattian) was mostly deposited in the oligophotic-mesophotic zone, in normal saline waters. The middle and upper parts of the Asmari Formation is characterized by euphotic-mesophotic biota (except for the Gharibi Ha section, SE of study area, where the sedimentation occur in aphotic situation in Burdigalian). The oligophotic zone is characterized by large and flat lepidocyclinids and nummulitids and corallinacean algae. Lens shaped rotalids abundantly thrived in the mesophotic zone. The euphotic zone is dominated by porcellaneous larger foraminifera and indicates well lit, highly translucent, shallowest part of the photic zone.

The biotic assemblages recognized within the Asmari Formation indicate a deposition in tropical to sub-tropical waters, as suggested by the presence of diverse large benthic foraminifera. Carbonate grain associations suggest a heterozoan assemblage for the Asmari Formation. Deposition of the Asmari Formation took place under oligotrophic to mesotrophic conditions in the study area.

From the Chattian to Aquitanian was a time of relative tectonic stability in the area. The deepening in the north of the study area is considered as a result of a regional tilting that started in the Late Burdigalian.

\section{Acknowledgements}

The authors would like to thank the University of Isfahan for providing financial support. The writers also wish to thank the National Iranian South 
Oil Company for support during field and laboratory work.

\section{References}

Adams, C., Bourgeois, E., 1967, Asmari biostratigraphy: Geological and Exploration Div., Iranian Oil Offshore Company: Report 1074, Unpublished.

Allahkarampour Dill, M., Seyrafian, A., VaziriMoghaddam, H., 2010, The Asmari Formation, north of the Gachsaran (Dill anticline), southwest Iran, facies analysis, depositional environments and sequence stratigraphy: Carbonates and Evaporites, 25(2), 145-160.

Allahkarampour Dill, M., Seyrafian, A., VaziriMoghaddam, H., 2012, Palaeoecology of the Oligocene-Miocene Asmari Formation in the Dill Anticline (Zagros Basin, Iran): Neues Jahrbuch für Geologie und Paläontologie Abhandlungen, 263(2), 167-184.

Amirshahkarami, M., Vaziri-Moghaddam, H., Taheri, A., 2007a, Paleoenvironmental model and sequence stratigraphy of the Asmari Formation in southwest Iran: Historical Biology, 19(2), 173-183.

Amirshahkarami, M., Vaziri-Moghaddam, H., Taheri, A., 2007b, Sedimentary facies and sequence stratigraphy of the Asmari Formation at Chaman-Bolbol, Zagros Basin, Iran: Journal of Asian Earth Sciences, 29(56), 947-959.

Bassi, D., Hottinger, L., Nebelsick, J.H., 2007, Larger foraminifera from the Upper Oligocene of the Venetian area, North-East Italy: Palaeontology, 50(4), 845-868.

Bassi, D., Nebelsick,J.H., 2010, Components, facies and ramps: Redefining Upper Oligocene shallow water carbonates using coralline red algae and larger foraminifera (Venetian area, northeast Italy): Palaeogeography,
Palaeoclimatology, Palaeoecology, 295(1-2), 258-280.

Be, A.W.H., 1977, An ecological, zoogeographic and taxonomic review of recent planktonic foraminifera: Oceanic Micropaleontology, 1, $1-100$.

Beavington-Penney, S.J., Racey, A., 2004, Ecology of extant nummulitids and other larger benthic foraminifera: applications in palaeoenvironmental analysis: Earth-Science Reviews, 67(3-4), 219-265.

Beydoun, Z.R., Hughes Clarke, M.W., Stoneley, R., 1992, Petroleum in the Zagros Basin: A Late Tertiary Foreland Basin Overprinted onto the Outer Edge of a Vast HydrocarbonRich Paleozoic-Mesozoic Passive-Margin Shelf, Chapter 11: American Association of Petroleum Geologists Memoir, 55, 309-339.

Bolli, H.M., 1957, Planktonic foraminifera from the Oligocene-Miocene Cipero and Lengua formations of Trinidad, B.W.I., in Loeblich, A.R., Tappan, H.Beckmann, J.P., Bolli, H.M., Gallitelli, E.M., Troelsen, J.C. (eds.), Studies in Foraminifery: Bulletin of the U.S. National Museum, 215 , 97-123.

Boreen, T.D., James, N.P., 1995, Stratigraphic sedimentology of Tertiary cool-water limestones, SE Australia: Journal of Sedimentary Research, 65(1), 142-159.

Bosence, D., 1983, Coralline algae from the Miocene of Malta: Palaeontology, 26, 147-173.

Brachert, T.G., Betzler, C., Braga, J.C., Martin, J.M., 1998, Microtaphofacies of a warmtemperate carbonate ramp (uppermost Tortonian/lowermost Messinian, southern Spain): Palaios, 13(5), 459-475.

Brandano, M., Frezza, V., Tomassetti, L., Cuffaro, M., 2009a, Heterozoan carbonates in oligotrophic tropical waters, The Attard member of the lower coralline limestone formation (Upper Oligocene, Malta): Palaeogeography, Palaeoclimatology, Palaeoecology, 274(1-2), 54-63. 
Brandano, M., Frezza, V., Tomassetti, L., Pedley, M., Matteucci, R., 2009b, Facies analysis and palaeoenvironmental interpretation of the Late Oligocene Attard Member (Lower Coralline Limestone Formation), Malta: Sedimentology, 56(4), 1138-1158.

Brasier, M.D., 1975, An outline history of seagrass communities: Palaeontology 18(4), 681-702.

Cahuzac, B., Poignant, A., 1997, Essai de biozonation de l'Oligo-Miocene dans les bassins européens a l'aide des grands foraminifères néritiques: Bulletin de la Societé Géologique de France, 168(2), 155-169.

Carannante, G., Esteban, M., Milliman, J.D., Simone, L., 1988, Carbonate lithofacies as paleolatitude indicators, problems and limitations: Sedimentary Geology, 60(1-4), 333-346.

Corda, L., Brandano, M., 2003, Aphotic zone carbonate production on a Miocene ramp, Central Apennines, Italy: Sedimentary Geology, 161(1-2), 55-70.

Cosovic, V., Drobne, K., Moro, A., 2004, Paleoenvironmental model for Eocene foraminiferal limestones of the Adriatic carbonate platform (Istrian Peninsula): Facies, 50, 61-75.

d'Orbigny, A., 1826, Tableau methodique de la classe des Cephalopodes: Annales des sciences naturelles, Zoologie, 7, 245-314.

Defrance, M.J.L., 1822, Lenticulites, in Guvier, M.F. (ed), Dictionnaire des Sciences naturelles, 25(laa-leo) Levrault F.G.: Strasbourg et Le Normant, Paris: 452-453.

Dunham, R., 1962, Classification of carbonate rocks according to depositional texture, in Ham, W.E., (ed.), Classification of carbonate rocks: AAPG Memoir 1, Tulsa, 108-121.

Ehrenberg, S.N., Pickard, N.A.H., Laursen, G.V., Monibi, S., Mossadegh, Z.K., Svånå, T.A., Aqrawi, A.A.M., McArthur, J.M., Thirlwall, M.F., 2007, Strontium isotope stratigraphy of the Asmari Formation (Oligocene - lower
Miocene), SW Iran: Journal of Petroleum Geology, 30(2), 107-128.

Elliott, G.F., 1962, More microproblematica from the Middle East: Micropaleontology, 8, 29-44.

Embry, A., Klovan, J., 1971, A late Devonian reef tract on northeastern Banks Island, NWT: Bulletin of Canadian Petroleum Geology, 19(4), 730.

Farzipour-Saein, A., Yassaghi, A., Sherkati, S., Koyi, H., 2009, Mechanical stratigraphy and folding style of the Lurestan region in the Zagros Fold-Thrust Belt, Iran: Journal of the Geological Society, 166(6), 1101-1115.

Feary, D.A., James, Noel P., 1995, Cenozoic biogenic mounds and buried Miocene(?) barrier reef on a predominantly cool-water carbonate continental margin - Eucla basin, western Great Australian Bight: Geology, 23(5), 427-430.

Flügel, E., 2010, Microfacies of Carbonate Rocks, Analysis, Interpretation and Application, $2^{\text {nd }}$ Edition: Springer-Verlag, Berlin Hiedelberg, $984 \mathrm{p}$.

Fornasini, C., 1904, Illustrazione di specie orbignyane di Foraminiferi institute nel,1826: Memoire della Reale Accademia della Scienze dell Instituto di Bologna 6(1), 1-17.

Geel, T., 2000, Recognition of stratigraphic sequences in carbonate platform and slope deposits: empirical models based on microfacies analysis of Palaeogene deposits in southeastern Spain: Palaeogeography, Palaeoclimatology, Palaeoecology, 155(3-4), 211-238.

Greig, D.A., 1935, Rotalia viennotti, an important foraminiferal species from Asia Minor and Western Asia: Journal of Paleontology 9, 523-526.

Halfar, J., Godinez-Orta, L., Mutti, M., ValdezHolguin, J., Borges, J., 2004, Nutrient and temperature controls on modern carbonate production: an example from the Gulf of California, Mexico: Geology, 32, 213-216. 
Hallock, P., 2001, Coral reefs, carbonate sedimentation, nutrients, and global change, in Stanley, G.D. (ed.), The History and Sedimentology of Ancient Reef Ecosystems: Kluwer Academic/Plenum Publishers, New York, 387-427.

Hallock, P., Glenn, E.G., 1986, Large foraminifera: a tool for paleoenvironmental analysis of Cenozoic carbonate depositional facies: Palaios, 1(1), 55-64.

Hemleben, C., Spindler, M., Anderson, O.R., 1989, Modem Planktonic Foraminifera: Springer, New York, 363 p.

Henson, F.R.S., 1937, Larger foraminifera from Aintab, Turkish Syria: Eclogae Geologicae Helvetiae, 30, 45-57.

Henson, F.R.S., 1950, Middle Eastern Tertiary Peneroplidae (Foraminifera) with remarks on the phylogeny and taxonomy of the family. Ph.D. thesis, Leiden (Wakefield), England, 70 p., (unpublished).

Heydari, E., 2008, Tectonics versus eustatic control on supersequences of the Zagros Mountains of Iran: Tectonophysics, 451(1-4), 56-70.

Heydari, E., Hassanzadeh, J., Wade, W.J., Ghazi, A.M., 2003, Permian-Triassic boundary interval in the Abadeh section of Iran with implications for mass extinction, Part 1: Sedimentology, Palaeogeography, Palaeoclimatology, Palaeoecology, 193, 405-423.

Hottinger, L., 1997, Shallow benthic foraminiferal assemblages as signals for depth of their deposition and their limitations: Bulletin de la Societé Géologique de France, 168(4), 491-505.

Iaccarino, S.M., Premoli-Silva, I., Biolzi, M., Foresi, M., Lirer, F., Petrizzo, M.R., 2005, Practical Manual of Oligocene to middle Miocene Planktonic Foraminifera: International School on Planktonic Foraminifera $4^{\text {th }}$ course: Università degli Studi di Perugia, Università degli Studi di Parma, Universita degli Studi di Milano, Perugia-Parma- Milano, 124 pp.
James, G.A., Wynd, J.G., 1965, Stratigraphic nomenclature of Iranian oil consortium agreement area: AAPG Bull, 49, 2182-2245.

Jones, B., Desrochers, A., 1992, Shallow platform carbonates, in Walker, R.G., James, N.P., (eds.), Facies Models: Response to Sea Level Change: Geological Association of Canada, 277-301.

Langer, M., Hottinger, L., 2000, Biogeography of selected "larger" foraminifera: Micropaleontology, 46, 57-86.

Langer, M.R., 1993, Epiphytic foraminifera: Marine Micropaleontology, 20(3-4), 235-265.

Laursen, G., Monibi, S., Allan, T., Pickard, N., Hosseiney, A., Vincent, B., Hamon, Y., vanBuchem, V., Moallemi, A., Druillion, G., 2009, The Asmari Formation Revisited, Changed Stratigraphic Allocation and New Biozonation: First International Petroleum Conference and Exhibition, Shiraz, 1-5.

Lees, A., Buller, A.T., 1972, Modern temperatewater and warm-water shelf carbonate sediments contrasted: Marine Geology, 13(5), 1767-1773.

Lemoine, P., Douvillé, R., 1904, Sur le genre Lepidocyclina Gümbel: Mémoires de la Société Géologique de France, sér. 12(32), $1-41$.

Mazzucchi, A., Tomassetti, L., 2011, Coral bioconstruction in a Burdigalian mixed siliciclastic-carbonate coastal system (Cala paraguano, Corsica): Mediterranean Earth sciences, 3, 15-23.

Michelotti, G., 1841, Saggio storico dei rizopodi caratteristici dei terreni supra-cretacei: Memorie della Societa Italiana delle Scienze, 22, 253-302.

Michelotti, G., 1861, Etudes sur le Miocène inférieur de l'Italie septentrionale, Natuurkundige: Verhandelingen van de Hollandsche Maatschappij der Wetenschappen te Haarlem, 15(2), 1-183. 
Mossadegh, Z.K., Haig, D.W., Allan, T., Adabi, M.H., Sadeghi, A., 2009, Salinity changes during Late Oligocene to Early Miocene Asmari Formation deposition, Zagros Mountains, Iran: Palaeogeography, Palaeoclimatology, Palaeoecology, 272, $17-36$.

Motiei, H., 1993, Stratigraphy of Zagros: Geological Survey of Iran, 583 pp.

Murray, J.W., 1973, Distribution and Ecology of Living Benthic Foraminiferids: Heinemann, London, 274 pp.

Nebelsick, J., Stingl, V., Rasser, M., 2001, Autochthonous facies and allochthonous debris flows compared: Early Oligocene carbonate facies patterns of the Lower Inn Valley (Tyrol, Austria): Facies, 44(1), 31-46.

Nelson, C.S., 1988, An introductory perspective on non-tropical shelf carbonates: Sedimentary Geology, 60(1-4), 3-12.

Pedley, M., 1998, A review of sediment distributions and processes in Oligo-Miocene ramps of southern Italy and Malta (Mediterranean divide): Geological Society, London, Special Publications, 149(1), 163-179.

Pomar, L., 2001, Ecological control of sedimentary accommodation: evolution from a carbonate ramp to rimmed shelf, Upper Miocene, Balearic Islands: Palaeogeography, Palaeoclimatology, Palaeoecology, 175(1-4), 249-272.

Pomar, L., Brandano, M., Westphal, H., 2004, Environmental factors influencing skeletal grain sediment associations: a critical review of Miocene examples from the western Mediterranean: Sedimentology, 51, 627-651.

Pomar, L., Bassant, P., Brandano, M., Ruchonnet, C., Janson, X., 2012, Impact of carbonate producing biota on platform architecture: Insights from Miocene examples of the Mediterranean region: Earth-Science Reviews, 113(3-4), 186-211.

Pomar, L., Hallock, P., 2008, Carbonate factories: A conundrum in sedimentary geology: EarthScience Reviews 87, 134-169.
Pomar, L., Mateu-Vicens, G., Morsilli, M., Brandano, M., 2014, Carbonate ramp evolution during the Late Oligocene (Chattian), Salento Peninsula, southern Italy: Palaeogeography, Palaeoclimatology, Palaeoecology, 404, 109-132.

Rahmani, A., Taheri, A., Vaziri-Moghaddam, H., Ghabeishavi, A., 2012, Biostratigraphy of the Asmari Formation at Khaviz and Bangestan Anticlines, Zagros Basin, SW Iran: Neues Jahrbuch für Geologie und Paläontologie Abhandlungen, 263(1), 1-16.

Rahmani, A., Vaziri-Moghaddam, H., Taheri, A., Ghabeishavi, A., 2009, A model for the paleoenvironmental distribution of larger foraminifera of Oligocene-Miocene carbonate rocks at Khaviz Anticline, Zagros Basin, SW Iran: Historical Biology: An International Journal of Paleobiology, 21(3), 215-227.

Reich, S., Di Martino, E., Todd, J.A., Wesselingh, F.P., Renema, W., 2015, Indirect paleoseagrass indicators (IPSIs): A review: EarthScience Reviews, 143, 161-186.

Reichel, M., 1937, Étude sur les Alveolines: Schweizerische Paläontologische Abhandlungen, 59(3), 95-147.

Reuter, M., Piller, W.E., Harzhauser, M., Berning, B., Kroh, A., 2010, Sedimentary evolution of a late Pleistocene wetland indicating extreme coastal uplift in southern Tanzania: Quaternary Research, 73(1), 136-142.

Reuss, A.E., 1850, Neue Foraminiferen aus den Schichten des Österreichischen ertiärbeckens: Denkschriften der Kaiserlichen Akademie der Wissenschaften / MathematischNaturwissenschaftliche Classe, 1, 365-390.

Romero, J., Caus, E., Rosell, J., 2002, A model for the palaeoenvironmental distribution of larger foraminifera based on late Middle Eocene deposits on the margin of the South Pyrenean basin (NE Spain): Palaeogeography, Palaeoclimatology, Palaeoecology, 179(1-2), 43-56. 
Schlumberger, C., 1893, Note sur les genres Trillina et Inderina: Bulletin de la Société Géologique de France, 21, 118-123.

Seyrafian, A., 2000, Microfacies and depositional environments of the Asmari Formation, at Dehdez area (a correlation across central Zagros basin): Carbonates and Evaporites, 15(2), 121-129.

Seyrafian, A., Vaziri-Moghaddam, H., Torabi, H., 1996, Biostratigraphy of the Asmari Formation, Burujen area, Iran: Journal of Sciences I.R. Iran, 7(1), 31-47.

Shabafrooz, R., Mahboubi, A., VaziriMoghaddam, H., Moussavi-Harami, R., Ghabeishavi, A., S.Al-Asam, I., 2015a, Facies analysis and carbonate ramp evolution of Oligo-Miocene Asmari formation in the Gachsaran and Bibi-Hakimeh oildfields and the nearby Mish Anticline, Zagros Basin, Iran: Neues Jahrbuch für Geologie und Paläontologie - Abhandlungen, 276(1), 121-146.

Shabafrooz, R., Mahboubi, A., Vaziri Moghaddam, H., Ghabeishavi, A., Moussavi Harami, R., 2015b, Depositional architecture and sequence stratigraphy of the OligoMiocene Asmari platform, Southeastern Izeh Zone, Zagros Basin, Iran: Facies, 61, DOI 10.1007/s10347-014-0423-3.

Smout, A.H., Eames, F.E., 1958, The genus Archaias (Foraminifera) and its stratigraphical distribution: Palaeontology, 1(3), 207-225.

Sooltanian, N., Seyrafian, A., Vaziri-Moghaddam, H., 2011, Biostratigraphy and paleoecological implications in microfacies of the Asmari Formation (Oligocene), Naura anticline (Interior Fars of the Zagros Basin), Iran: Carbonates and Evaporites, 26(2), 167-180.

Tolderlund, D.S., Allan, W.H.B.xe, 1971, Seasonal Distribution of Planktonic Foraminifera in the Western North Atlantic: Micropaleontology, 17(3), 297-329.
Tomassetti, L., Brandano, M., 2013, Sea level changes recorded in mixed siliciclasticcarbonate shallow-water deposits: The Cala di Labra Formation (Burdigalian, Corsica): Sedimentary Geology, 294, 58-67.

Van Buchem, F.S.P., Allan, T.L., Laursen, G.V., Lotfpour, M., Moallemi, A., Monibi, S., Motiei, H., Pickard, N.A.H., Tahmasbi, A.R., Vedrenne, V., Vincent, B., 2010, Regional stratigraphic architecture and reservoir types of the Oligo-Miocene deposits in the Dezful Embayment (Asmari and Pabdeh Formations) SW Iran: Geological Society, London, Special Publications, 329(1), 219-263.

Vaziri-Moghaddam, H., Kimiagari, M., Taheri, A., 2006, Depositional environment and sequence stratigraphy of the Oligo-Miocene Asmari Formation in SW Iran: Facies, 52(1), $41-51$.

Vaziri-Moghaddam, H., Seyrafian, A., Taheri, A., Motiei, H., 2010, Oligo-Miocene ramp system (Asmari Formation) in the NW of the Zagros basin, Iran: Microfacies, paleoenvironment and depositional sequence: Revista Mexicana de Ciencias Geológicas, 27(1), 56-71.

Wilson, J.L., 1975, Carbonate Facies in Geologic History: Springer-Verlag, New York, 471 pp.

Wilson, M.E.J., Vecsei, A., 2005, The apparent paradox of abundant foramol facies in low latitudes: their environmental significance and effect on platform development: EarthScience Reviews, 69(1-2), 133-168.

Wynd, J.G., 1965, Biofacies of Iranian oil consortium agreement area: Iranian Oil Operating Company: Report 1082, Unpublished. 